Author accepted version. Final publication as: Carrera-Hernandez, J.J \& Gaskin, S.J. (2008) Spatio-temporal analysis of potential

aquifer recharge: Application to the Basin of Mexico, Journal of Hydrology, 353(3-4): 228-246. doi:10.1016/j.jhydrol.2008.02.012

\title{
Spatio-temporal analysis of potential aquifer recharge: Application to the Basin of Mexico
}

\author{
J. J. Carrera-Hernández ${ }^{a, b, c, *}$, S. J. Gaskin ${ }^{a}$ \\ ${ }^{a}$ McGill University, Department of Civil Engineering and Applied Mechanics, 817 \\ Sherbrooke Street West, Montreal QC, $\mathrm{H}_{3} \mathrm{~A}$ 2K6, Canada \\ binternational Institute for Applied Systems Analysis (IIASA). Schlossplatz 1, \\ Laxenburg, A-2361, Austria. \\ ${ }^{\mathrm{c} C u r r e n t}$ address: University of Alberta, Earth and Atmospheric Sciences. Edmonton, \\ $A B$.
}

\begin{abstract}
Regional estimates of aquifer recharge are needed in data-scarce regions such as the Basin of Mexico, where nearly 20 million people are located and where the Basin's aquifer system represents the main water source. In order to develop the spatio-temporal estimates of aquifer recharge and to analyze to what extent urban growth has affected aquifer recharge, this work presents a daily soil water balance which uses different vegetation and soil types as well as the effect of topography on climatological variables and evapotranspiration. The soil water balance was applied on a daily time step in the Basin of Mexico for the period 1975-1986, obtaining an annually-lumped potential recharge flow of $10.9-23.8 \mathrm{~m}^{3} / \mathrm{s}(35.9-$ $78.1 \mathrm{~mm})$ in the entire Basin, while the monthly values for the year with the largest lumped recharge value $(1981=78.1 \mathrm{~mm})$ range from $1 \mathrm{~m}^{3} / \mathrm{s}(0.3 \mathrm{~mm})$ in December to $87.9 \mathrm{~m}^{3} / \mathrm{s}(23.7 \mathrm{~mm})$ in June. As aquifer recharge in the Basin mainly occurs by subsurface flow from its enclosing mountains, urban growth has had a minimal impact on aquifer recharge, although it has diminished recharge in the alluvial plain.
\end{abstract}

Key words: Aquifer recharge, urban growth, soil water balance, Mexico City, Basin of Mexico, evapotranspiration.

* Corresponding author.

Email addresses: jaime.carrera@mail.mcgill.ca (J. J. Carrera-Hernández), 
The Analysis of the spatial and temporal variability of potential aquifer recharge is needed in order to improve the understanding of regional and local groundwater flow systems as well as to prevent pollution of aquifers. The variability of recharge events is important in both arid and semi-arid areas where from a long-term analysis, evapotranspiration greatly exceeds rainfall but where short, high intensity rainfall events largely exceed evapotranspiration, thus making more water available for recharge. Recharge can be classified based on its spatial occurrence: diffuse recharge is derived from precipitation or irrigation on large areas, while focused (localized) recharge occurs at topographic depressions such as streams and lakes (Scanlon et al., 2002). Aquifer recharge was classified by Lerner et al. (1990) as actual recharge, which is the water that reaches the water table and potential recharge, which is the water that might be available for recharge but which due to specific situations (e.g. high water table) is transformed into run-off. Different methods can be used to analyze aquifer recharge such as direct measurement, water balance methods, Darcian approaches, tracer techniques and empirical methods developed for particular case studies (Lerner et al., 1990).

Regional estimates of aquifer recharge need to consider both its spatial and temporal variability as this will improve its estimation (Lerner et al., 1990). In addition, a regional hydrogeological conceptual model needs to be developed before attempting to estimate recharge, as it can occur as subsurface flow, from streams located above the water table (i.e. loosing streams), or as in a common situation in alluvial basins defined as Mountain Block Recharge (MBR), which is used to define the flow that enters an aquifer through the mountains by which it is limited. Studies that have developed estimates of MBR can be classified depending on whether they focus on the mountain block or on the basin (Wilson and Guan, 2004). Basin-centered methods include the calibration of groundwater flow models which limit the modeling domain to porous media or to the application of Darcy's law along the mountain block, while mountain block approach methods include isotope methods, empirical relations between MBR and precipitation or by lumped water balances (Wilson and Guan, 2004). A large number susan.gaskin@mcgill.ca (S. J. Gaskin). 
of studies have attempted to estimate MBR, mainly in the Western United States: Wasiolek (1995) developed both seasonal and annual estimates of MBR through a simple water balance in five different watersheds to estimate seasonal and annual MBR to the Tesuque aquifer system in Santa Fe, New Mexico while Maurer et al. (1996) determined subsurface flow to Eagle Valley in Nevada using Darcy's law and the chloride balance method, Wilson and Guan (2004) describe seven studies that estimated MBR in New Mexico, Utah, Colorado, Texas and Arizona.

A good overview of methods to estimate regional aquifer recharge is given by de Vries and Simmers (2002), while an inter-comparison study of recharge estimates using different methods is given by Flint et al. (2002) who compared the outcome of water balance techniques, Darcy's law in the unsaturated zone, chloride mass balance, atmospheric radionuclides and empirical approaches in the Yucca mountain in Nevada. The recharge values obtained with each method were different, and ranged from o to $300 \mathrm{~mm} / \mathrm{yr}$, and according to these authors no single method adequately characterizes recharge. The difficulty of estimating aquifer recharge has been mentioned by several authors such as Sophocleous (1995) who states that it is one of the most difficult and uncertain factors to measure and that there is no established practical methodology to satisfactorily regionalize recharge estimates. The main factors that control recharge are climate, soils, vegetation/land use and topography (Faver et al., 1996; Keese et al., 2005). The role that vegetation plays on aquifer recharge varies according to different authors: Keese et al. (2005) mention that its presence diminishes recharge, while others (Berndtsson and Larson, 1987) mention that it increases infiltration. Keese et al. (2005) studied 13 regions in Texas with different climate, vegetation and soil types. They found that vegetation reduces aquifer recharge as areas covered with trees have lower recharge values than those areas covered by grass due to the tree's deeper roots; for their study areas, mean annual precipitation explained $80 \%$ of the variation in recharge. The fact that vegetation diminishes recharge is explained by Finch (1998): when root depth increases, aquifer recharge decreases as larger soil moisture deficits develop and need to be replenished before the soil reaches field capacity, which is when the soil will start to drain. However, the plants' water demand should also be considered here as a pine does not require the same amount of water as an arid shrub. 
Despite the existing difficulties and uncertainties, regional estimates of aquifer recharge are needed even when data are scarce, as is the case for the Basin of Mexico, home to nearly 20 million people and to whom the Basin's aquifer system is the main water supply source. Unfortunately existing data in the region do not suffice to develop a detailed infiltration model and existing data are limited to the Basin's southern area, where the Mexico City Metropolitan Zone (MCMz) is located. In addition, estimates of the spatial distribution of recharge in the study area are needed in order to analyze the impact of urban growth both on its quantity and quality. Accordingly, a methodology to estimate potential aquifer recharge in the Basin (which mainly occurs as MBR) was developed, which can also be applied to other areas. This methodology estimates potential aquifer recharge through a simple soil water balance which considers different vegetation types, soil units and the effect of topography on climatological variables such as rainfall and temperature, as described in the following sections.

\section{Development of a simple daily soil water balance}

The daily soil water balance developed for this study, considers the evolution of a depletion depth caused by a water deficit when plant water requirements are not met. This simple bucket model uses daily evapotranspiration which is computed according to the FAO-56 methodology (Allen et al., 1998) and the Near Surface Soil Storage (Nsss) term introduced by Rushton et al. (2006), which partitions water that enters the soil water balance into a component that remains in the upper soil (NSss) and another component that diminishes soil depletion through the use of a fractional storage coefficient $\left(F_{s t}\right)$. The daily soil water balance is expressed as:

$$
D_{i}=i f\left(E T_{a c t} \leq S M_{i}, D_{i-1}-S M_{i}\left(1-F_{s t}\right), D_{i-1}+E T_{a c t_{i}}-S M_{i}\right)
$$

where $D_{i}$ represents depletion (e.g. water deficit with respect to the soil's field capacity), $S M_{i}$ soil moisture and $E T_{a c t_{i}}$ actual evapotranspiration on day $i$ in [mm]. Before applying this equation, rainfall $(R)$ is partitioned into runoff and water that enters the soil water balance under the assumption that all excess rainfall is transformed into runoff, where excess rainfall is the rainfall that exceeds the infiltration rate. In this case the infiltration rate is 
considered equal to the saturated conductivity of the soil $\left(K_{s}\right)$; Accordingly, $S M_{i}$ is determined as:

$$
S M_{i}=i f\left(R_{i}>K_{s}, K_{s}+N S S S_{i-1}, R_{i}+N S S S_{i-1}\right)
$$

where $S M_{i}$ is limited by the soil's field capacity, and $N S S S_{i}$ is determined by:

$$
N S S S_{i}=i f\left(E T_{a c t_{i}} \leq S M_{i},\left(S M_{i}-E T_{a c t}\right) \times F_{s t}, 0\right)
$$

From (1, 2 and 3) it can be seen that the first factor required is $N_{S S S}$, which in this work was originally set to zero for the first day of the simulation, as December and January are months in which rainfall is generally absent in the study area, thus it is logical to assume this term to be equal to zero by starting the soil water balance in January, while the soil's depletion is equal to its maximum value, which in this case was set to each soil's Total Evaporable Water (TEW) as suggested by Allen et al. (1998).

The soil's water deficit is a function of $E T_{\text {act }}(\mathbf{1})$, which in turn is limited by the available soil moisture; when $E T_{\text {act }}$ is less than or equal to the available soil moisture, $D_{i}$ is equal to the depletion of the previous day minus the fraction of $S M_{i}$ available to diminish the soil's water deficit (e.g. water that is not retained near the soil surface). When $E T_{a c t_{i}}$ is larger than $S M_{i}$, then it is limited by the available moisture and $D_{i-1}$ will increase by this deficit. Soil moisture is determined using daily rainfall that enters the soil water balance, and $N S S S_{i-1}$ as shown in (3) when $E T_{a c t_{i}} \leq S M_{i}$ through the use of the $F_{s t}$ coefficient; when this condition is not met, then all water is taken by $E T_{a c t}$. Finally, actual evapotranspiration $\left(E T_{a c t}\right)$ is determined by:

$$
E T_{a c t}=K_{c} E T_{\circ}
$$

where $E T_{\circ}$ represents potential evaporation and $K_{c}$ is a coefficient based on each vegetation type, soil water stress and soil evaporation, computed by:

$$
K_{c}=K_{s t} K_{c b}+K_{e}
$$

where $K_{c b}$ is a factor that varies according to the vegetation type of interest, its growing stage and relative humidity. This coefficient is multiplied 
by a stress factor $K_{s t}$ in order to consider the effect of soil water stress and an evaporation coefficient $K_{e}$ which considers the evaporation due to wetting of the soil surface. The way in which these parameters are obtained is explained in the following sections.

\subsection{Reference evapotranspiration}

In this work the FAO-56 Penman-Monteith equation is used to determine reference evapotranspiration $\left(E T_{\circ}\right)$, considering the spatial distribution of net radiation, topography and both minimum and maximum temperature. This section is based on Allen et al. (2005), Allen (2000) and Allen et al. (1998), where a detailed description of the procedure is given. The PenmanMonteith equation is given by:

$$
E T_{\circ}=\frac{0.408 \Delta\left(R_{n}-G\right)+\gamma \frac{900}{T+273} u_{2}\left(e_{s}-e_{a}\right)}{\Delta+\gamma\left(1+0.34 u_{2}\right)}
$$

where $E T_{\circ}$ is given in [mm/day] and $R_{n}$ represents net radiation at the crop surface $\left[\mathrm{MJ} / \mathrm{m}^{2}\right.$ day], $G$ soil heat flux density $\left[\mathrm{MJ} / \mathrm{m}^{2}\right.$ day], $T$ mean daily air temperature at $2 \mathrm{~m}$ height $\left[{ }^{\circ} \mathrm{C}\right], u_{2}$ wind speed at $2 \mathrm{~m}$ height $[\mathrm{m} / \mathrm{s}], e_{s}$ saturation vapour pressure $[\mathrm{kPa}], e_{a}$ actual vapour pressure $[\mathrm{kPa}], \Delta=$ slope vapour pressure curve $\left[\mathrm{kPa} /{ }^{\circ} \mathrm{C}\right]$ and $\gamma$ the psychometric constant $\left[\mathrm{kPa} /{ }^{\circ} \mathrm{C}\right]$. Using elevation $(z)$, these factors can be estimated as shown in Appendix A

Due to the lack of humidity data, this variable was determined by assuming that dew point temperature is near the daily minimum temperature $\left(T_{\min }\right)$, as suggested in Allen et al. (1998), thus $e_{a}$ can be obtained by using $T_{\text {min }}$ (eq. A.3).

\subsection{Vegetation parameters}

Actual Evapotranspiration $\left(E T_{a c t}\right)$ is obtained by applying a crop coefficient $\left(K_{c b}\right)$ to the reference evapotranspiration $\left(E T_{\circ}\right)$ value. The $K_{c b}$ factor is represented by a curve which is divided into an initial, development, middle, and late growing seasons. To develop this curve, the initial $\left(K_{c b_{\text {ini }}}\right)$, mid-season $\left(K_{c b_{\text {mid }}}\right)$ and final $\left(K_{c b_{\text {end }}}\right)$ values are needed, some of which are found in the 
FAO-56 publication. These values represent conditions for a sub-humid climate $(\mathrm{RH}=45 \%)$ and a wind velocity of $2 \mathrm{~m} / \mathrm{s}$; however, when this methodology is used for different humidity conditions, the crop coefficients need to be adjusted when their values are above 0.45 as follows:

$$
K_{c b}=K_{c b}+\left(0.04\left(u_{2}-2\right)-0.004\left(R H_{\min }-45\right)\right)\left(\frac{h}{3}\right)^{0.3}
$$

where $h$ is mean maximum plant height [m], $R H_{\text {min }}$ mean value for minimum daily relative humidity during the mid-season [\%]. Relative humidity is computed from daily temperature as:

$$
R H=100 \frac{e_{a}}{e^{\circ}\left(T_{\text {mean }}\right)}=\frac{e^{\circ}\left(T_{\text {min }}\right)}{e^{\circ}\left(T_{\text {mean }}\right)}
$$

\subsection{Soil evaporation}

The evaporation coefficient $\left(K_{e}\right)$ of $(5)$ is computed with:

$$
K_{e}=K_{r}\left(K_{c \max }-K_{c b}\right) \leq f_{e w} K_{c \max }
$$

where $K_{r}$ represents the way in which evaporation decreases in proportion to the amount of water remaining in the surface soil layer, $K_{c b}$ is the crop coefficient obtained through (7), $f_{\text {ew }}$ is the soil fraction that is exposed both to solar radiation and rainfall, and $K_{c_{\max }}$ is the maximum value of $K_{c}$ following rain or irrigation obtained as:

$$
K_{c_{\max }}=\max \left(\left\{1.2+\left[0.04\left(u_{2}-2\right)-.004\left(R H_{\min }-45\right)\right]\left(\frac{h}{3}\right)\right\},\left\{K_{c b}+0.05\right\}\right)
$$

where $h$ is mean maximum plant height [m], $R H_{\text {min }}$ mean value for minimum daily relative humidity during the mid-season [\%] and $K_{c b, h}$ represents $K_{c b_{\text {mid }}}$ for full cover vegetation under $R H_{\text {min }}=45 \%$ and $u_{2}=2 \mathrm{~m} / \mathrm{s}$ estimated as:

$$
K_{c b, h}=1.0+0.1 h
$$

where $K_{c b_{\text {mid }}} \leq 1.20$ when $\mathrm{h}>2$ meters. The value obtained with this equation is adjusted to other climatological conditions by (7). The soil fraction 
that can be wetted and which is also exposed to solar radiation $\left(f_{e w}\right)$ is obtained by:

$$
f_{e w}=\min \left(1-f_{c}, f_{w}\right)
$$

where $f_{w}$ is the average fraction of soil surface wetted by irrigation or precipitation and which varies between 0.01 to 1 , while $f_{c}$ is the average fraction of soil surface covered by vegetation and determined by:

$$
f_{c}=\left(\frac{K_{c b}-K_{c_{\min }}}{K_{c_{\text {max }}}-K_{c_{\text {min }}}}\right)^{1+0.5 h}
$$

On which $f_{c}$ is a value between o and 0.99 , and $K_{c_{\text {min }}}$ is the minimum $K_{c}$ for dry bare soil with no ground cover with an approximate value of 0.15. The limitation of (12) assumes that the fraction of soil that is wetted occurs within the fraction of soil exposed to sunlight and ventilation. Finally, $\mathrm{K} r$, the remainder term of (9), represents the way in which evaporation decreases in proportion to the amount of water remaining in the surface soil layer, obtained as follows:

$$
K_{r}=\frac{T E W-D_{e, i-1}}{T E W-R E W}
$$

where $R E W$ represents the Readily Evaporable Water which ranges from 5 to $12 \mathrm{~mm}$ (Allen, 2000) and TEW is the Total Evaporable Water, defined as the maximum depth of water that can be evaporated from the soil and computed as:

$$
T E W=1000\left(\theta_{F C}-0.5 \theta_{W P}\right) Z_{e}
$$

where $\theta_{F C}$ and $\theta_{W P}$ represent soil water content at field capacity and wilting point respectively, expressed in $\left[\mathrm{m}^{3} / \mathrm{m}^{3}\right]$, and $Z_{e}$ represents the depth of the surface soil layer that is subject to evaporation and ranges from 0.10 to 0.15 $\mathrm{m}$. 
In order to obtain a more realistic value of $E T_{a}$, eq. [5 includes a water stress factor $K_{s t}$ which is obtained as:

$$
K_{s t}=\frac{T A W-D_{r}}{T A W-R A W}=\frac{T A W-D_{r}}{(1-p) T A W}
$$

where $K_{s t}$ is a transpiration reduction factor dependent on available soil water, $D$ represents depletion, computed from (1), $R A W$ is readily available water, and represents the fraction $(p)$ of total available water $(T A W)$ in the root zone that a plant can extract without suffering water stress.

$$
T A W=1000\left(\theta_{F C}-\theta_{W P}\right) Z_{r}
$$

where $Z_{r}$ is rooting depth, which varies according to each vegetation type.

\section{The Basin of Mexico}

The Basin of Mexico, located in the central part of Mexico has a mean elevation of 2240 meters above sea level (masl) and is home to Mexico City and its Metropolitan Zone (MCMZ) with nearly 20 million inhabitants (Fig. 囷). The Mсмz is located in the southern and lowest region of the Basin and is bounded to the south by the Sierra Chichinautzin and to the west by the Sierra de las Cruces, which both limit urban growth in these directions (Fig. 团). According to Durazo and Farvolden (1983), annual precipitation in the lower part of the Basin is approximately $700 \mathrm{~mm}$, while evaporation can reach $1600-1700 \mathrm{~mm}$. However, it is important to mention that these two variables exhibit a large spatio-temporal variability in the study area as the surrounding mountains located south of the Basin receive large amounts of rain with low temperatures due to the abrupt change in elevation. The Basin's aquifer system is comprised of a Quaternary alluvial unit (Qal) which reaches a maximum thickness of $800 \mathrm{~m}$ in the southern part of the Basin and from which groundwater is extracted at a depth of $300 \mathrm{~m}$ (Herrera et al., 1989). This unit is bounded to the south by the Sierra Chichinautzin, and is comprised of highly fractured Quaternary basalts $(\mathrm{Qb})$ that also outcrop in other regions of the Basin located northwards such as Chiconautla, Tizayuca, 
Apan and Tecocomulco. The vertical hydraulic conductivity value $\left(K_{v}\right)$ for this unit is estimated to be around $2.4 \times 10^{-4} \mathrm{~m} / \mathrm{s}$ (DGCOH, 1994). In the southern part of the Basin, the Qal unit is limited to the East by the Sierra Nevada with an elevation above 5000 masl and to the West by the Sierra de las Cruces; the foothills of these Sierras correspond to the Tarango formation (T), comprised of tuff, pummice and lahar (Mooser and Molina, 1993) with $K_{v}$ values from $4.0 \times 10^{-7} \mathrm{~m} / \mathrm{s}$ to $6.9 \times 10^{-5} \mathrm{~m} / \mathrm{s}(\mathrm{DGCOH}$, 1994). In the central part of the Basin, the Qal unit is found below a lacustrine unit (Qla) which reaches a maximum depth of $300 \mathrm{~m}$ in the Chalco sub-basin (Vázquez-Sánchez and Jaimes-Palomera, 1989) with a $K_{v}$ value of $5 \times 10^{-9}$ $\mathrm{m} / \mathrm{s}$, acting as a confining unit in the central part of the aquifer.

The large extraction rates from the Basin's aquifer system have caused a continuous drawdown of the groundwater level, which on average is $I$ $\mathrm{m} / \mathrm{yr}$ and reaches a maximum value of nearly $2.5 \mathrm{~m} / \mathrm{yr}$ north of Mexico City (Carrera-Hernández and Gaskin, 2007a); in turn, these large drawdown rates have triggered land subsidence, which in some areas reaches a rate of $0.4 \mathrm{~m} / \mathrm{yr}$ (Strozzi et al., 2003). Despite the fact that the aquifer system represents the main source of water supply in the Basin, no regional studies have been undertaken. To date, studies have focused mainly on the area where the MCMz is located, a focus that needs to change (Carrera-Hernández and Gaskin, 2007a). As part of this lack of regional studies, estimates of regional recharge to the aquifer are also missing. In order to improve the understanding of and to develop management policies for the Basin's aquifer system, the way in which aquifer recharge occurs needs to be understood. To achieve this, the present work uses spatial information on soils, land cover and climatological variables to determine potential aquifer recharge, as defined by Lerner et al. (1990)

\section{Previous work in the Basin of Mexico}

The Basin of Mexico is surrounded by mountainous terrain (Fig. 囷), accordingly, the estimation of $E T_{\circ}$ has to consider the effect that slope, aspect and shadows have on global radiation. Accordingly, this work aims to analyze the hydrological processes that occur both on the mountains that surround the Basin and in the Valley they enclose, as aquifer recharge occurs mainly 


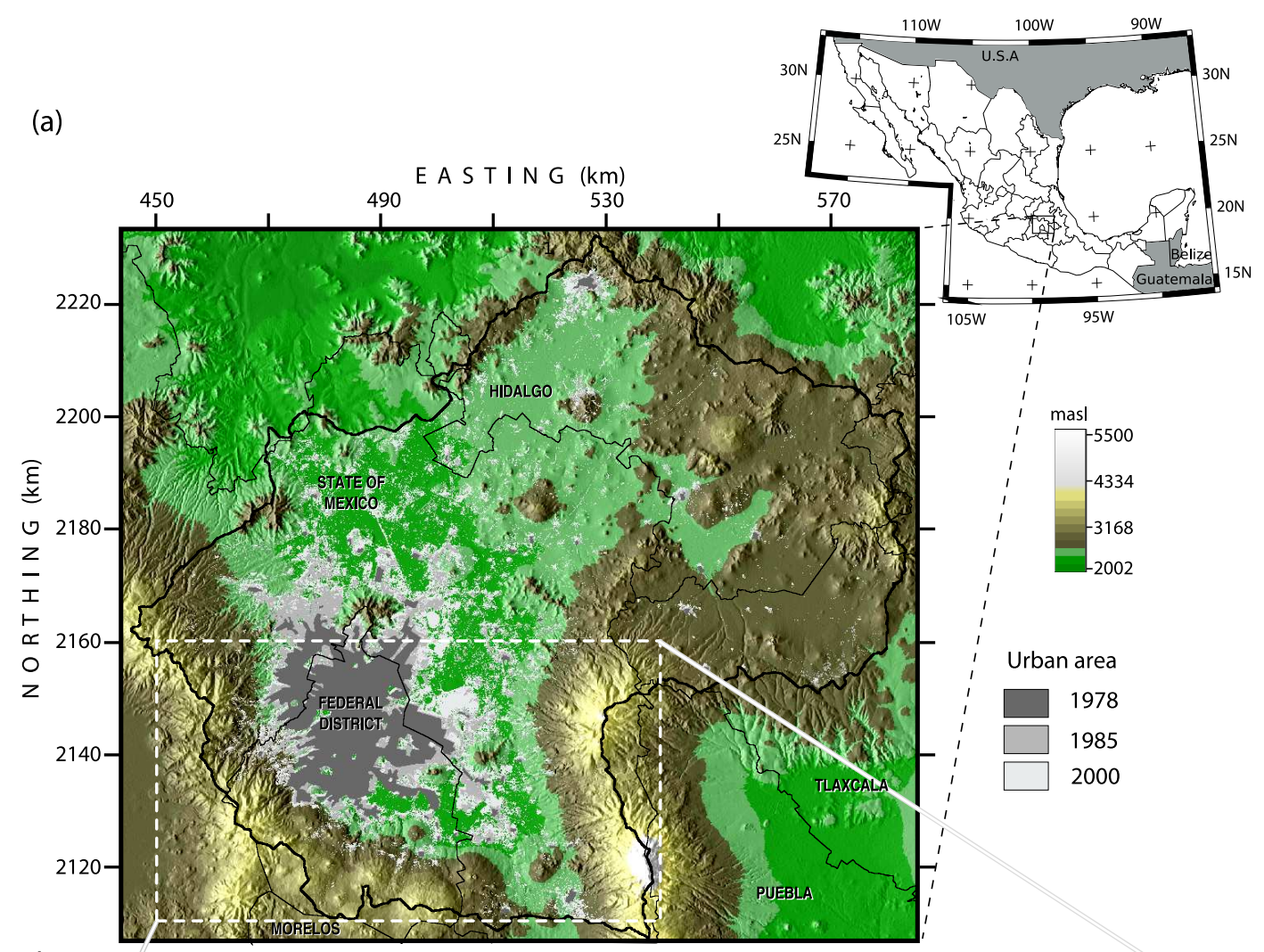

(b)

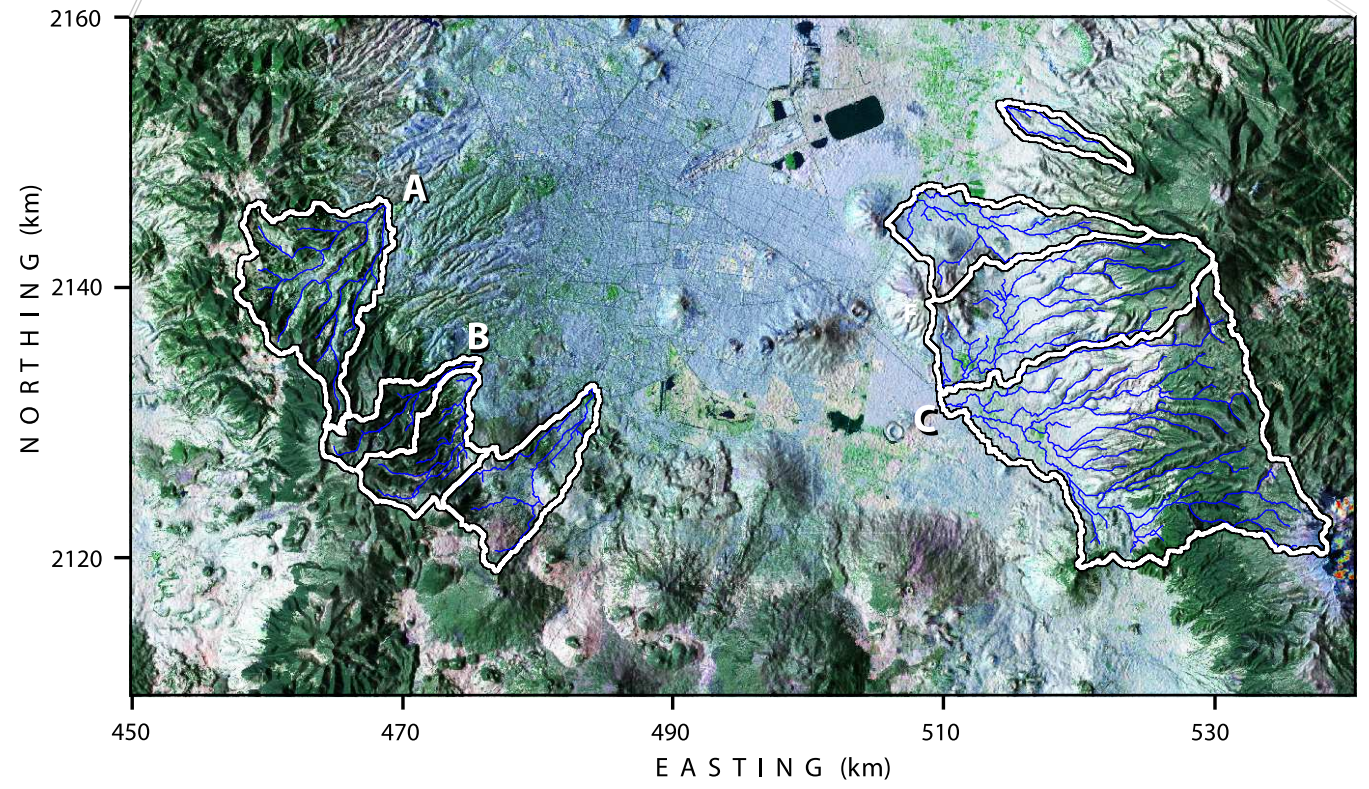

Fig. 1. Location of the Basin of Mexico showing: (a) topography and urban areas for 1978, 1985 and 2000, (b) Subbasins used to validate and calibrate the rainfall-runoff model: (A) Hondo, (B) Magdalena, (C) Compañía. Urban areas for 1978 were digitized, while the areas for 1985 and 2000 were derived from LANDSAT-TM and ETM+ imagery, respectively. The subbasins are shown on a false color composite developed from LANDSAT-ETM+ imagery acquired in 2000, topography and shaded relief developed from SRTM data 
in the form of MBR. Some authors have previously attempted to determine recharge in some areas of the Basin such as Huizar-Álvarez et al. (2003) who developed a groundwater flow model for the Pachuca-Zumpango area, in the northern part of the Basin using a constant and uniform recharge value of $2.92 \mathrm{~m}^{3} / \mathrm{s}$; however no details as to why this rate was chosen are given. Birkle et al. (1998) developed a "long-term" water balance for the Basin by using rainfall data from 1980-1985 and computing actual evapotranspiration based on the empirical relation $E T_{\text {actual }}=P-\lambda P^{2}$ where $\lambda=\frac{1}{0.8+0.14 T}$. The DGCOH (1994) used a recharge value of $15.6 \mathrm{~m}^{3} / \mathrm{s}$ as input to its groundwater flow model for the region where the MCMz is located, while Ortega and Farvolden (1989) estimated aquifer recharge as a percentage of precipitation in the three different Sierras that surround the Basin to the south: The Sierra Chichinautzin (42\%), Las Cruces $(30 \%-40 \%)$ and Nevada (40\%-50\%), using data from 1967 for the Sierra Chichinautzin, and both 1976 (ET) and 1983 (runoff) for the other two Sierras.

The attempts undertaken so far in the study area do not consider the effect that different vegetation types have on the hydrological processes and they have used limited climatological data. In order to overcome this problem, this work presents a methodology to estimate potential evapotranspiration at the basin scale using data which are generally available for large scale areas, such as hard copy maps, DEM, satellite imagery and climatological data, as illustrated in Fig. [2.

In order to develop the daily soil water balance, the Basin of Mexico Hydrogeological Database (вмндв) (Carrera-Hernández and Gaskin, 2007b) which contains climatological, spatial and hydrometric data was used. As illustrated in Fig. 2, the daily soil water balance requires the spatial distribution of climatological variables, which are used to obtain reference evapotranspiration $\left(E T_{\circ}\right)$. Actual evapotranspiration $\left(E T_{a c t}\right)$ is determined using the FAO-56 methodology (Allen et al., 1998) through the use of (ET०) and different coefficients such as a vegetation-dependent coefficient $\left(K_{c b}\right)$, a water stress coefficient $\left(K_{s t}\right)$ and a soil evaporation $\left(K_{e}\right)$ coefficient. This methodology was selected in order to account for different vegetation types in the Basin, instead of only relying on temperature and rainfall data. To determine $E T_{\circ}$ an albedo map is needed in addition to other topography-related data such as an aspect (e.g. degrees from north of each slope) and slope map as indicated in Fig. 2. A land cover map is needed in order to obtain 


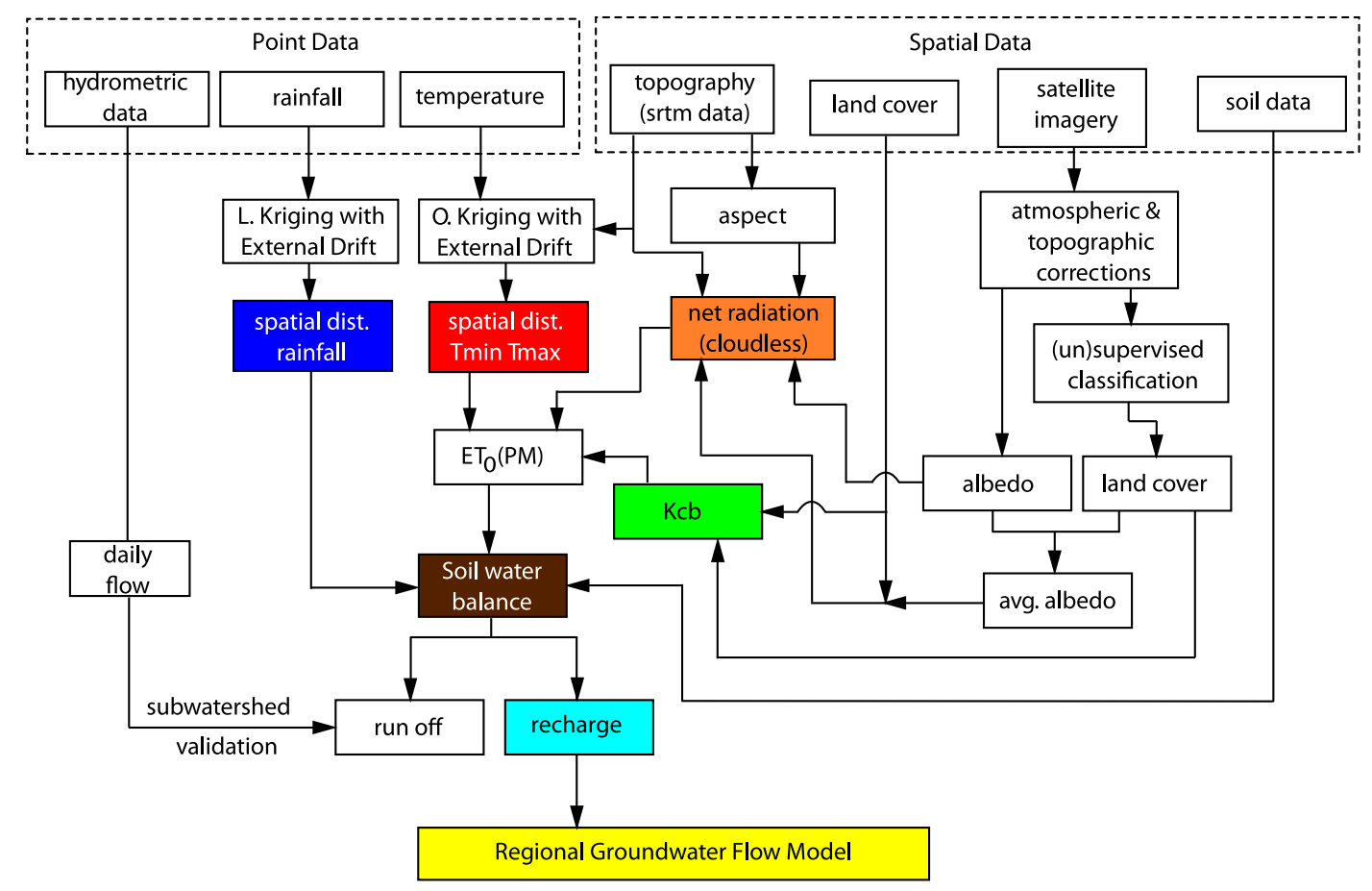

Fig. 2. Proposed approach to determine the spatio-temporal distribution of potential aquifer recharge in the Basin of Mexico and its use as boundary condition in a regional groundwater flow model

$E T_{a c t}$, as a different $K_{c b}$ value is used for each vegetation type which also varies throughout the year to account for the vegetation's growing stage. To obtain this information, different types of data can be used such as land cover maps developed either from satellite imagery for recent years or hard copy maps when satellite data are not available as was done in this study. The daily soil water balance was calibrated and validated using three watersheds located in the Basin's southern region (Fig. 囷(b)) by comparing the observed and the computed daily flow volume. The basin of the Hondo river is located in the Sierra de las Cruces and has an area of $103 \mathrm{~km}^{2}$, the Magdalena river basin is located in the Sierra Chichinautzin with an area of 31 $\mathrm{km}^{2}$ and finally, the La Compañia river basin is located in the southernmost area of the Basin, in the Sierra Nevada, with an area close to $300 \mathrm{~km}^{2}$. What follows is a description of the model and its implementation; however, a more detailed description is given in Carrera-Hernández (2007). 
Before the model could be applied in the Basin of Mexico, the spatial distribution of the different variables had to be obtained, a task achieved by processing point and spatial data with GRASS (GRASs development team, 2007) and the $\mathrm{R}$ statistical software ( $\mathrm{R}$ Development Core Team, 2005). As a first step, a digital elevation model (DEM) at 30 meters resolution was obtained by resampling a $90 \mathrm{~m}$ resolution DEM obtained from the Shuttle Radar Topography Mission (SRTM) using the regularized spline with tension and smoothing algorithm of Mitasova and Mitas (1993). This resolution was required as surface albedo maps developed from satellite images need to be corrected for both topographic and atmospheric effects (Sioberg and Horn, 1983). The SRTM data was also resampled to a $200 \mathrm{~m}$ resolution DEM following the same procedure, in order to develop the spatial distribution of climatological variables; this resolution was chosen in order to: (a) account for the effects of topography on both temperature and rainfall as a $200 \mathrm{~m}$ grid is considered to be appropriate in order to represent the variation of topographically dependent variables (Hutchinson and Galland, 1999), and (b) these climatological variables were developed with the idea of being used in the present study which in turn will be used as a boundary condition in a regional groundwater flow model. Therefore this resolution was used to develop the required data and to run the daily soil water balance. In order to develop the spatial distribution of climatological variables, topography was used as an auxiliary variable through the application of Kriging with External Drift (KED) in the case of both minimum and maximum temperature, while for rainfall, this was achieved by applying Kriging with External Drift in a local neighborhood $\left(\operatorname{KED}_{l}\right)$, as explained in Carrera-Hernández and Gaskin (2007c).

As previously mentioned, the proposed methodology uses satellite imagery to develop both albedo maps and land-cover classification maps; however, the satellite images had to be corrected for both atmospheric and topographic effects. Atmospheric correction was acomplished by applying the Dark Object Substraction (DOs) technique (Chavez, 1088) and by considering different optical depth values for each band (Chavez, 1996). The effect of topography affects radiance due to shadows, thus the Landsat images were corrected for terrain effects using the C-correction method (Teillet et al., 
1982) as it has been found that it leads to classification improvements in forest and forest-stand/forest-type land covers (Itten and Mver, 1993). It should be mentioned that satellite imagery could have been used to estimate $f_{c}$ though the use of the Normalized Difference Vegetation Index (NDVI) as shown in Carlson and Riplev (1997) or the Enhanced Vegetation Index (EvI) as used by Mu et al. (2007); however, this option was not explored in this work but could be used to analyze the evolution of $f_{c}$ with remote sensing data from the Moderate Resolution Imaging Spectroradiometer (MODIS).

\subsection{Spatial distribution of solar radiation}

In order to account for the influence of topography (e.g. slope, orientation and elevation) in $E T_{\circ}$, the $r$. sun module developed by Súri and Hofierka (2004) was used to determine $R_{n}$. This module gives its output as three different raster maps: 1 ) direct radiation (e.g. cloudless direct beam radiation), 2) diffuse radiation and 3) reflected radiation. This module computes the daily sum of solar irradiation [Wh $\mathrm{W}^{-2}$ ] from sunrise to sunset and requires topography in the form of a DEM, and both an aspect and a slope map (both of which are derived from the DEM), the spatial distribution of the Linke atmospheric turbidity index, ground albedo and clear sky index (i.e. cloud cover).

Broad band surface albedo was computed from Landsat ЕTM+/TM imagery according to the relationship developed by Liang (2001) after applying both atmospheric and terrain corrections:

$$
\alpha_{\text {short }}=0.356 \alpha_{1}+0.130 \alpha_{3}+0.373 \alpha_{4}+0.085 \alpha_{5}+0.072 \alpha_{7}-0.0018
$$

where $\alpha_{i}$ represents at ground-reflectance. The albedo maps developed with this methodology are shown in Fig. 3 for both 1985 and 2000. As expected, albedo exhibits low values in the mountainous areas that surround the Basin (as they are forested areas) and near null values in water bodies. The 2000 albedo map was developed only for comparison, as at this moment climatological data were only gathered for up to 1990, but future work will focus on updating the вмнDв with recent data. The white regions shown in Fig. 3. (a) represent cloud cover, located on areas outside of the study area. 


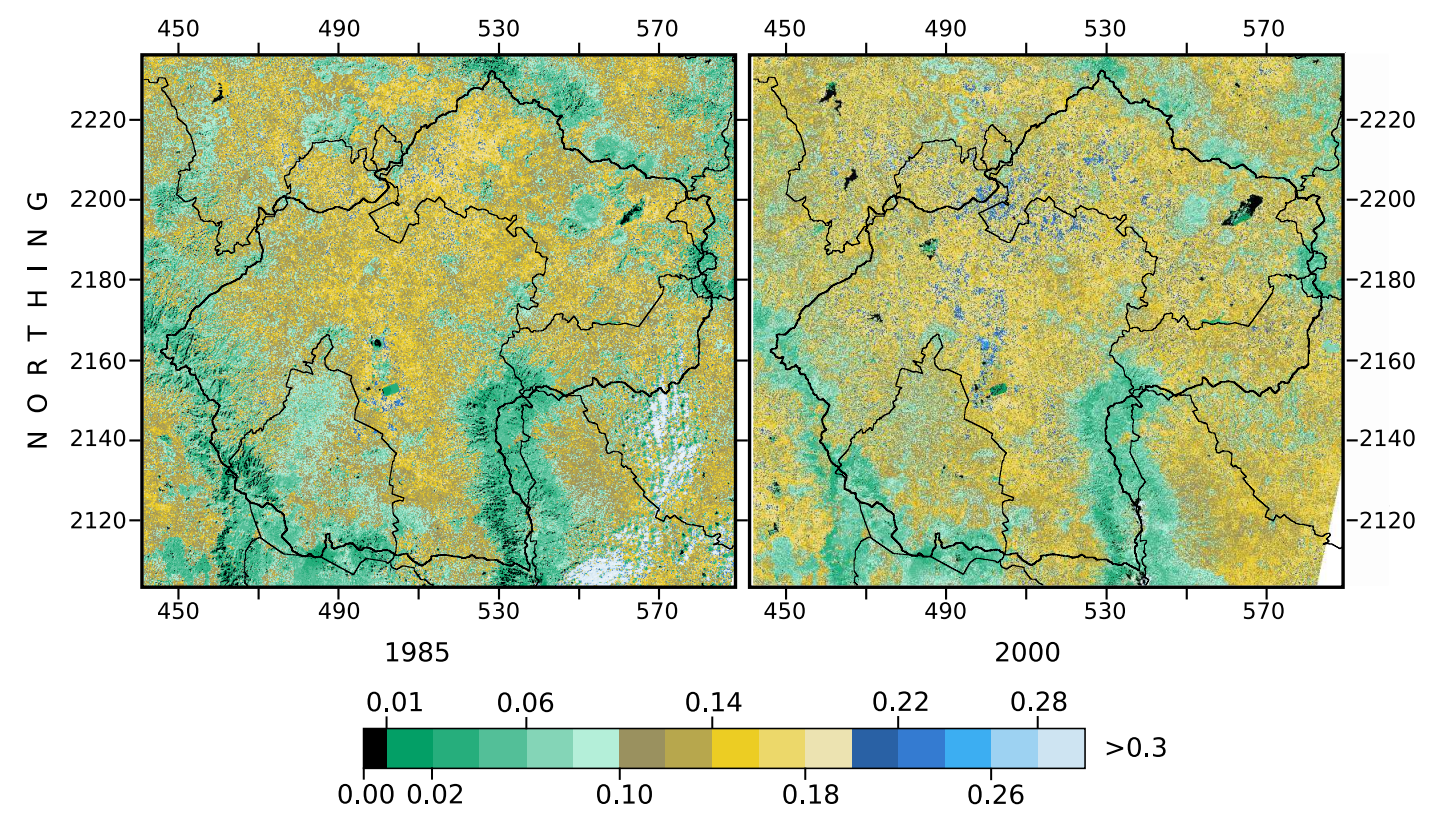

Fig. 3. Albedo maps developed from LANDSAT imagery

Table 1

Monthly averaged Linke turbidity factor for different locations in the Basin of Mexico

\begin{tabular}{lcccccccccccc}
\hline Location & Jan & Feb & Mar & Apr & May & Jun & Jul & Aug & Sep & Oct & Nov & Dec \\
\hline D.F. & 3.4 & 3.6 & 3.6 & 3.8 & 4.0 & 3.7 & 3.1 & 3.3 & 3.2 & 3.0 & 3.2 & 2.7 \\
Pachuca & 3.2 & 3.4 & 3.3 & 3.3 & 3.8 & 3.3 & 2.8 & 3.0 & 2.8 & 2.8 & 2.9 & 2.6 \\
Naucalpan & 3.4 & 3.6 & 3.6 & 3.9 & 4.1 & 3.7 & 3.0 & 3.3 & 3.2 & 3.0 & 3.2 & 2.8 \\
Amecameca & 3.4 & 3.7 & 3.6 & 3.8 & 4.0 & 3.6 & 3.0 & 3.2 & 3.1 & 3.0 & 3.2 & 2.6 \\
Apan & 3.3 & 3.5 & 3.5 & 3.6 & 3.9 & 3.5 & 2.9 & 3.1 & 3.0 & 2.9 & 3.1 & 2.6 \\
\hline
\end{tabular}

In order to account for time variability of the Linke atmospheric turbidity value, the monthly values shown in Table 1 were used for all years of the simulation. These values were obtained from http://www.soda-is.com.

\subsection{Landcover classification and vegetation parameters}

The main goal of this work was to analyze the impact that land cover change through urban growth has had on aquifer recharge. Accordingly, a set of land cover maps covering the study area are required. The analysis was 

restricted to the period from 1975-1986 in order to make use of the available data: a hard copy land cover map for 1978 and a Landsat image for 1985; in addition, although climatological data were available for up to 1990, 1986 was chosen as for this year climatological data are still available for a large number of climatological stations.

The required land cover maps were developed from available hard copy maps for 1978 and from LANDSAT imagery for 1985 acquired in January. The Basin of Mexico is covered by two sets of Landsat images, thus for a given acquisition date the images of row 26 and paths 46 and 47 are required. Land cover in the southern part of the Basin was classified by using the 26/47 images while its northern part was classified by using the 26/46 images as reflectance values for overlapping pixels were different even after applying the required corrections. Accordingly, training areas were developed separately based on the 1978 land cover map, where no land cover change was expected to have occurred.

The satellite images were classified into different land cover types using the Sequential Maximum a posteriori algorithm (Bouman and Shapiro, 1994) which uses a Multiscale Random Field for Bayesian image segmentation. This algorithm was chosen because McCauley and Engel (1995) and Bouman and Shapiro (1994) found that its classification accuracy was better than the one obtained with the Maximum Likelihood (ML) algorithm; in addition, this classification method is part of GRASs image processing modules. A visual comparison between the 1978 and 1985 land cover maps (Fig. 4) was used as a proxy for classification plausibility, as no ground truth data were available to this end. Both maps show good agreement between the forested, grassland and shrub-covered areas along with the location of water bodies. In the northeastern region of the Basin, the Tecocomulco lake is shown in both maps (although its areal extent is larger in 1985) and the appearance of a rectangular-shaped water body west of the Federal District is noticeable in 1985, as this water body, the Nabor Carrillo lake was created in the early 8os. Due to the resolution of the satellite images, the "irrigated grass" land cover type was added in 1985 for which grass areas located in soccer stadiums were used as training areas.

Urban growth in the Basin between 1978 and 1985 can be easily seen by comparing Fig. 4(a) and Fig. 4(b). From these figures, it can be inferred that 


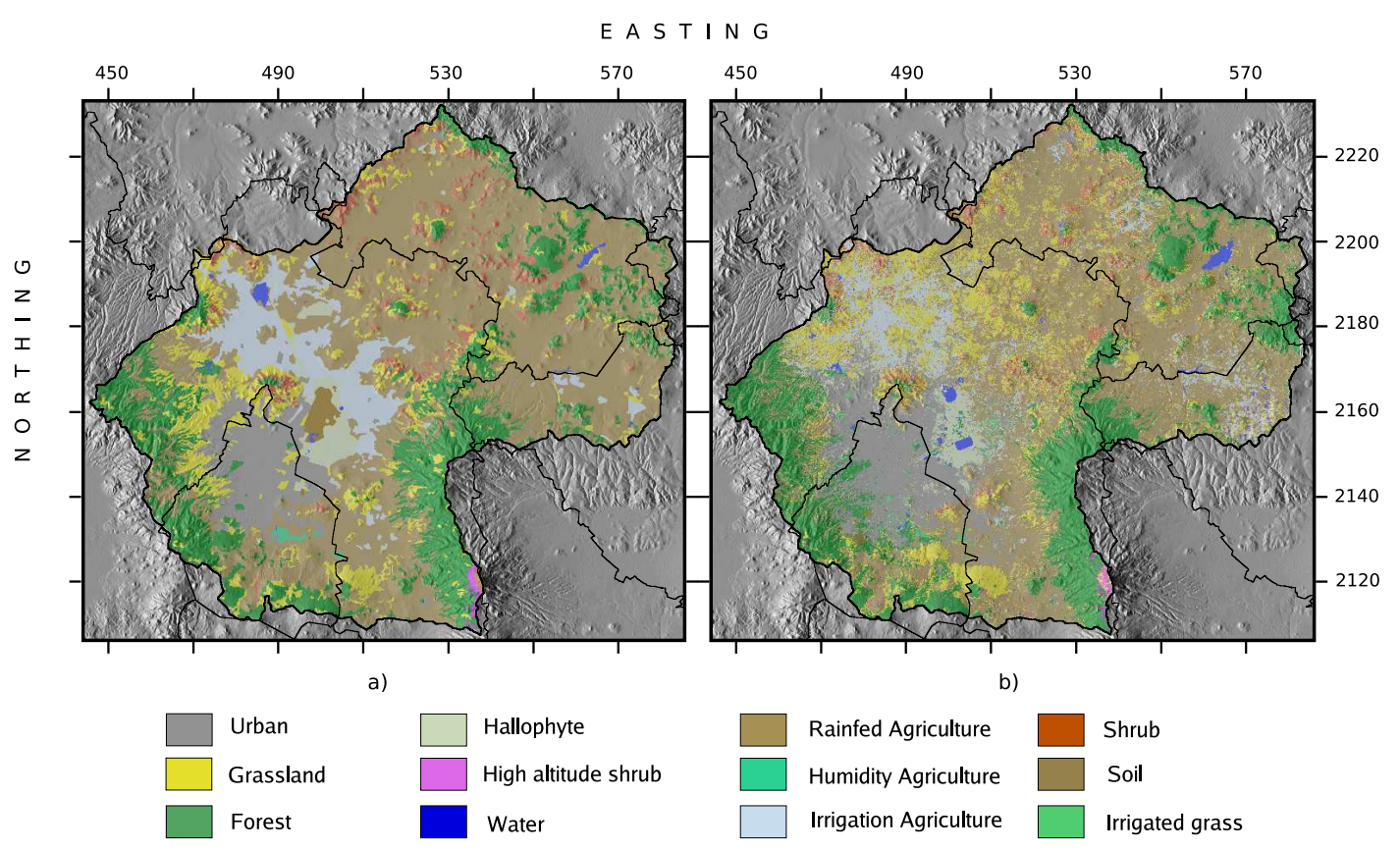

Fig. 4. Landcover maps for the Basin of Mexico for two different years: (a) 1974 derived from hard copy maps and (b) 1985 derived from LANDSAT images.

urban growth is limited to the south by the Siera Chichinautzin (Fig. 团(a)), which explains why urban growth has mainly occurred north of the Federal District in Tlalnepantla, on the left side of Sierra Guadalupe. As seen in Fig. 4. urban growth has occurred at the expense of grassland areas northwards of the Federal District, while eastwards urban areas have been developed in rain-fed agricultural areas. After land cover classification was achieved, a vegetation coefficient was assigned to each cover type, for which the values included in Allen et al. (1998) were used with a $15 \%$ reduction in order to account for non-pristine conditions, as recommended by Allen (2000). The details of this implementation (e.g. values and season lengths) are given in Carrera-Hernández (2007).

The mountains that enclose the Basin are covered by forests of different types: in the Sierra Chichinautzin they are comprised of Pinus hartwegii found on Lithosol and Abies religiosa which is locally known as Oyamel and found on thick soils on steep slopes (Islebe and Velázquez, 1994). In the Sierra Nevada, oak forest, mixed forest, fir forest, pine forest and alpine grassland are found between 2800 and 4100 masl (Sánchez-González and López-Mata, 2005). Grasslands in the study area are mainly comprised of Bouteloua gracilis, while hallophyte vegetation, which is restricted to the lowest region of the Basin (Fig. 4), where the Texcoco lake used to be, is comprised of Distichlis spicata; in contrast, alpine grasslands (locally known as Zacatonal) 
are found in the high mountains that surround the Basin, being found as high as 4300 masl (Rzedowski, 1975) and represented by Festuca and Calamagrostis, reaching up to $1 \mathrm{~m}$ in height (Rzedowski, 1975). Although initially different $K_{c b}$ values were intended to be used for each grassland type, these three types were grouped and a single $K_{c b}$ value was used. The last natural vegetation type in the Basin corresponds to shrubs, which are represented by Opuntia streptacantha or Nopal cardón and are limited to the northern region of the Basin (Fig. (4); ; $K_{c b}$ value of 0.15 was used as this is a vegetation found in arid regions and is expected to have low water demands. Regarding the agricultural areas, one maize cycle was assumed for rain-fed areas, while two cycles were assumed to take place in areas under irrigation, the first one being for maize and the second one for alfalfa. Finally, humidity agriculture was assumed to take place throughout the year as water canals and chinampas are located in the the region of Xochimilco which is a remaining part of the Basin's lake, which is why the $K_{c b}$ values for a wetland were used (Table 12, Allen et al. (1998)).

\section{$5 \cdot 3$ Soil properties}

The spatial distribution of the soil's hydraulic properties was obtained by digitizing two paper maps at a 1:250,000 scale, acquired from the Mexican Institute of Geography, Statistics and Informatics (INEGI). As expected in a volcanic region, Andosols are found in the southwestern region of the Basin (Fig/5(a)). It is interesting to note that these soils, which exhibit excellent internal drainage due to their high porosity and a high moisture content (EAO, 2001) are located in those regions with the largest precipitation rates in the Basin and that they are located above fractured basalt (i.e. Sierra Chichinautzin), thus hinting that large recharge rates are to be expected in this region.

Along the Sierra Nevada, which is also another region with large precipitation rates, Regosols and Cambisols are found. Regosols, which are located in the Iztaccíhuatl volcano and the Sierra Santa Catarina are soils found in eroding lands and composed of unconsolidated materials thus having low water holding capacity and large permeability to water, while Cambisols, which are young soils with high porosity and good water holding capacity (EAO, 2001) are found in a small region in the Sierra de las Cruces, in some 


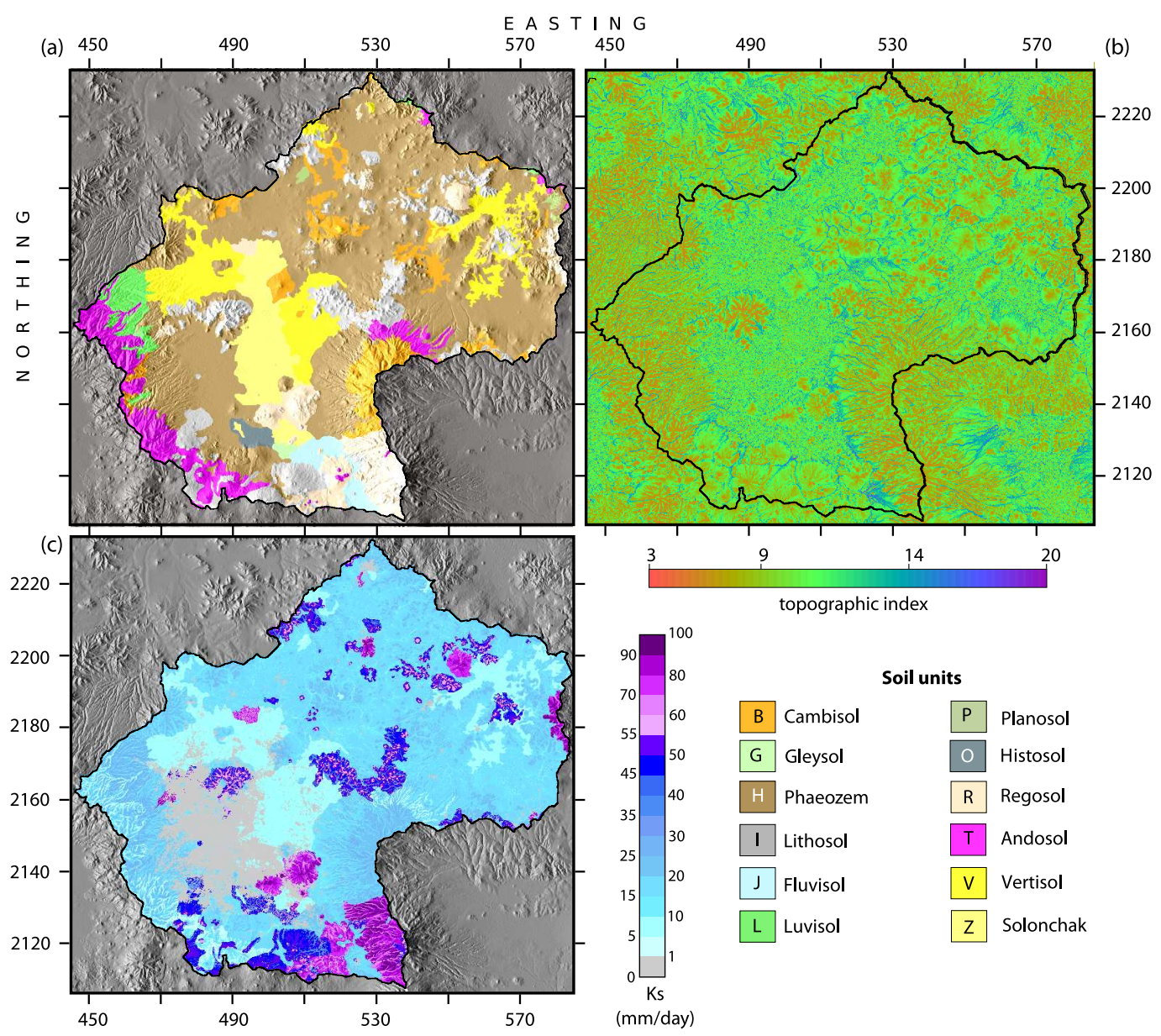

Fig. 5. Topography dependent saturated conductivity of soils in the Basin of Mexico: (a) Soil units, (b) Topographic index and (c) Saturated conductivity which also shows the location of urban areas, as $K_{s}=0$ was assigned to them.

hilly areas in Hidalgo and north of Sierra Nevada. The region of Xochimilco, (where the only wetland in the Basin is located) is covered by Histosol, which is formed in poorly drained basins or depressions whose highland areas have a high precipitation/evapotransipration ratio and which are associated with Vertisols in lacustrine environments. As shown in Fig. F(a), Vertisols, which have more than $30 \%$ clay below the first $20 \mathrm{~cm}(\mathrm{FAO}, 2001)$ are found in the Basin's valley and are associated with Zolonchaks in dry climates and to Phaeozems in humid climates. Both of these soils are found in the Basin: Zolonchak, which is a salty soil is found in what used to be the Texcoco lake while Phaeozems, which are soils rich in Organic Matter are the main soil unit in the Basin (Fig. [5(a)).

Before the soil water budget is computed, rainfall needs to be partitioned into runoff and water that enters the soil as shown in (1). The first step to achieve this partition was to assign a $K_{s}$ value to each soil unit based 
on published data and compare the daily runoff volume obtained by these values with the daily volume measured in three rivers: Hondo, Magdalena and Compañía (Fig. 目). These basins were selected because they have larger records and the recorded volumes showed no problems when they were screened. In addition, each basin comprises different soil units in different percentages: The Magdalena is mainly covered by Andosol (92\%) and Phaeozem (6\%), the Hondo basin by Andosol (52\%), Phaeozem (25\%), Cambisol (13\%) and Luvisol (8\%) while the Compañía basin by Regosol (45\%), Phaeozem (17\%), Cambisol (16\%), Fluvisol (14) and Lithosol (4\%). The use of a uniform $K_{s}$ value poorly represented the amount of rainfall that was partitioned into runoff; in addition the $K_{S}$ values for each soil unit had a lot of variability.

Due to the variability of $K_{s}$, an auxiliary variable based on topography was used, as erosion at the hilltop moves fine sediments to the hill-foot, as shown for a German catchment by Merz and Plate (1997). In addition, Rawls and Pachepsky (2002) mention that soils at positions with a high slope have smaller water retention within a given textural group, as soils on steep slopes have coarser textures. Accordingly, the Kirkby index (Kirkby, 1975) (also known as topographic index) is used as an auxiliary variable, as this index represents the propensity of a given point to develop saturated conditions (Beven et al., 1990):

$$
\lambda_{i}=\ln \left(\frac{a}{\tan (\beta)}\right)
$$

where $a$ is the area of the hill-slope per unit contour length that drains to a given point $(i)$ and $\tan (\beta)$ represents the local surface slope at that point, giving a spatial distribution in the Basin as shown in Fig. 5.(b). This index was used as an auxiliary variable to assign different $K_{s}$ values within a given soil unit through the use of a linear relationship: $K_{s_{\min }}$ value within a soil unit was used for those areas with a large topography index, while $K_{s_{\max }}$ was assigned to those areas with a small topography index, producing the spatial distribution of $K_{s}$ as shown in Fig. [5(c) where the largest $K_{s}$ values are found for Regosols, followed by Lithosols. The $K_{s}$ pattern assigned through the use of $\lambda$ is clearly seen, as low $\lambda$ values correspond to large $K_{s}$ values within a given soil unit. In addition, Fig. [5.(c) also shows urban areas in gray color, which were assigned a $K_{s}=0$. 


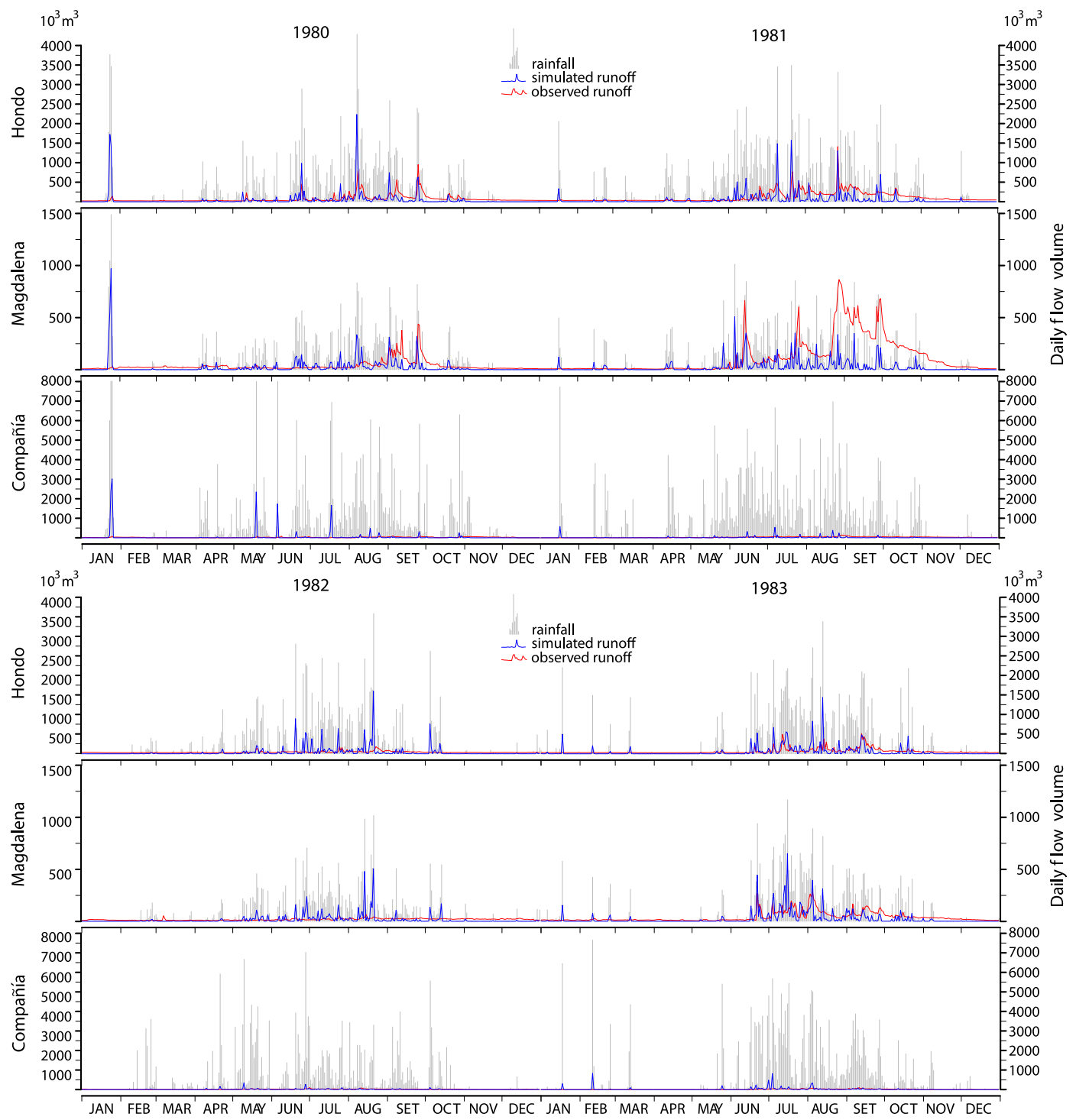

Fig. 6. Validation of runoff estimates for the Hondo, Magdalena and Compañía river basins in: (a) 1980, (b) 1981, (c) 1982 and (d) 1983

The $K_{s}$ values for each soil unit were calibrated by using three different watersheds in the southern part of the Basin. This calibration was undertaken for 1983 and then validated for years 1980, 1981 and 1982 (Fig. 6), by using a lumped daily value for simulated runoff, thus assuming that no lateral flow occurs as this process is not simulated.

\footnotetext{
When comparing the observed and the simulated values it should be kept in mind that the goal was not to simulate runoff, but rather to get an estimate of its volume variation through a simple approach: no interception is considered to occur in addition to neglecting lateral flow. Although the validation years were selected as they had more continuity on their records, some errors are evident as for the Magdalena basin in 1981 (Fig. 6(c)) mea-
} 
sured run-off is larger than the estimated rainfall. The simulated flow volumes react with a peak whenever a large precipitation event occurs, which is not the case for the observed volumes; this is notorious in January of 1980 (Fig. 6(a)) for the three watersheds as a large precipitation event occurred over three days which in turn caused a large simulated volume but a small peak in the observed volumes. Overall, estimated runoff volumes are acceptable, as observed hydrograph peaks are generally reproduced though, in general, the simulated values are larger than those observed. The idea behind this methodology was to develop a boundary condition for a regional groundwater flow model using the Unsaturated-Zone Flow (UZF1) package (Niswonger et al., 2006) of MODFLOW-2005 (Harbaugh, 2005). Accordingly, although the present validation was limited to comparing observed and simulated runoff, it is considered to be satisfactory, as an uncertainty analysis and further validation will be made as part of the regional groundwater flow model.

The final soil parameters required are the soil's field capacity $\left(\theta_{F C}\right)$ and wilting point $\left(\theta_{W P}\right)$ which are required to determine Total Evaporable Water, Total Available Water and Readily Available Water. Unfortunately as in the case of $K_{s}$, no data were available in the study area, as the only study in the region that treats these variables is the one of Bell (1993) who analyzed sixty nine samples in Chalco and found that the levels of Soil Organic Matter (som) were primarily related to altitude. Sixty two of these samples were taken near the Chalco area, while the remainder were collected outside of the Basin of Mexico on soil that has been cultivated for more than 50 years. However, even though no more research on these variables has been done in the Basin, Baties (1996) developed values of Available Water Capacity (AWC) for different FAO soil units as shown in Table 2

text The values shown in Table 2 were used in order to determine Readily Evaporable Water (REW) and Total Evaporable Water (TEW) from the relationship of these variables and AWC as shown in Table 19 of Allen et al. (1998). The factors used to obtain TEW and REW from AWC were 1.5 and 0.5 respectively. 
tabular

Table 2

Available Water Capacity per FAO soil unit by textural class ( $\mathrm{mm}$ ) to a depth of one meter, after Baties (1996)

\begin{tabular}{llrrrr}
\hline & Soil Unit & Coarse & Medium & Fine & All \\
\hline B & Cambisol & 115 & 130 & 130 & 130 \\
G & Gleysol & 117 & 119 & 129 & 122 \\
H & Phaeozem & 109 & 123 & 120 & 122 \\
I & Lithosol & - & 13 & 13 & 13 \\
J & Fluvisol & 82 & 120 & 114 & 116 \\
L & Luvisol & 57 & 90 & 87 & 89 \\
N & Nitosol & - & 85 & 74 & 75 \\
O & Histosol & - & - & - & 480 \\
R & Regosol & 80 & 120 & 107 & 100 \\
T & Andosol & 188 & 193 & 141 & 187 \\
V & Vertisol & - & 130 & 130 & 130 \\
Z & Solonchak & 51 & 133 & 190 & 135 \\
\hline
\end{tabular}

\section{Spatio-temporal distribution of potential aquifer recharge: results and} discussion

The daily soil water balance was applied to the entire Basin, after obtaining an acceptable partition of rainfall into runoff and water that enters the soil. This daily soil water balance was run from 1975 to 1986 with the goal of estimating the impact that urban growth has had on aquifer recharge. In order to exemplify the spatio temporal distribution of rainfall, $E T_{a c t}$ and recharge, Fig. 7 shows the spatial distribution of their accumulated values for June of 1980, 1981, 1982 and 1983 in order to use the same years used in Fig. 6 , 


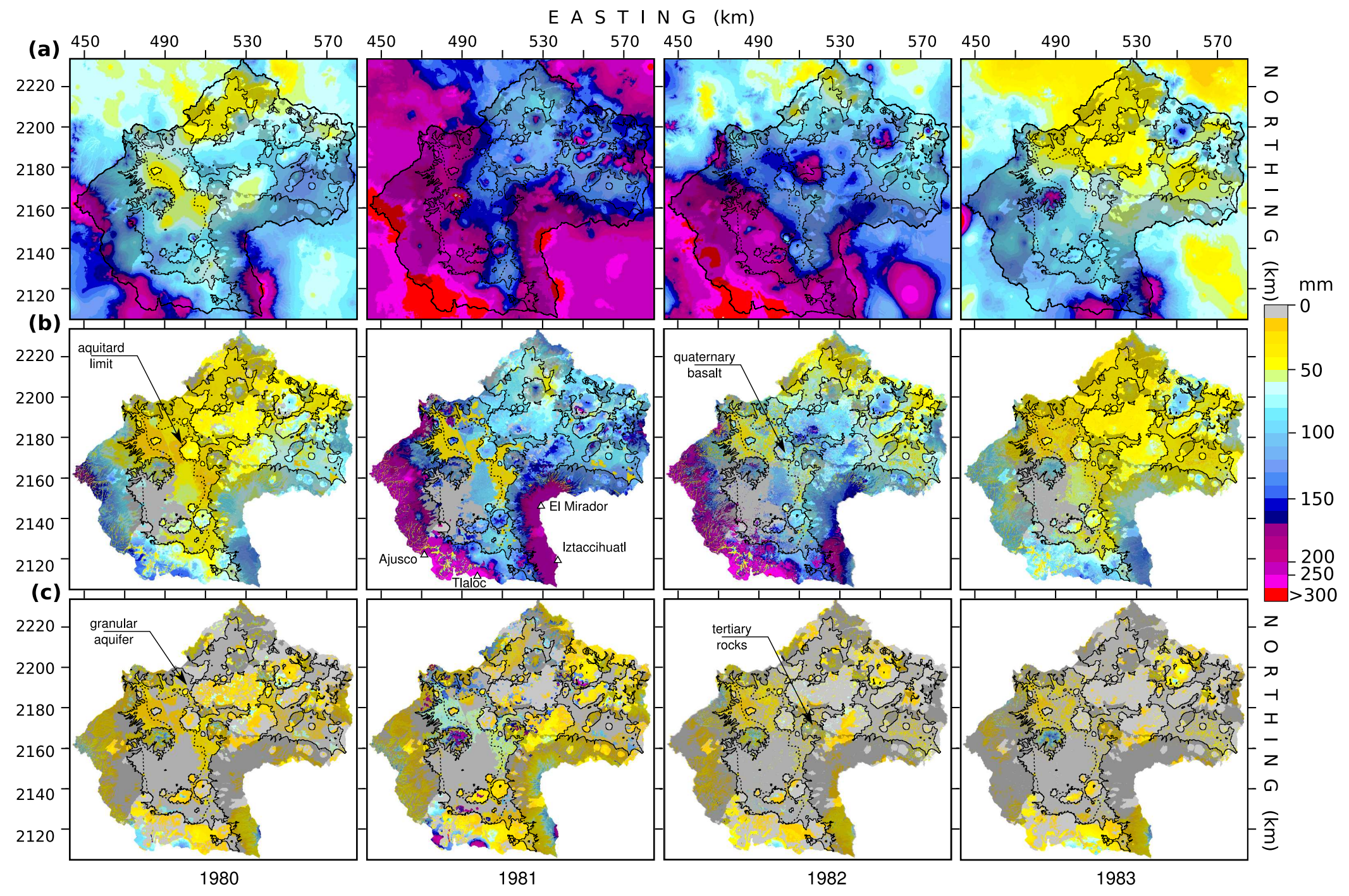

Fig. 7. Spatial distribution of monthly (a) rainfall, (b) actual evapotranspiration and (c) potential recharge in the Basin of Mexico for June of 1980-1983. Dark-shadowed areas represent tertiary rocks, while light-shadowed areas represent the granular aquifer. Quaternary basalts are not covered by shadows. 
The largest precipitation rates for these four years are observed in the mountains that enclose the basin, in particular in the southwestern region (Fig. 7(a)), with rainfall depths above $300 \mathrm{~mm}$ for three of these four years, while June 1981 was the month with the largest rainfall events. The effect of these events on $E T_{a c t}$ (which includes soil evaporation as shown by (4) and (5)) is evident by comparing their spatial distribution (Fig. 7(a) and (b)) in addition, it is interesting to note that forests are located in those regions showing large rainfall events, which is expected as their $E T$ is close to $E T_{\circ}$. By looking at the $E T_{\text {act }}$ patterns in the Sierra de las Cruces (Fig. $7(\mathrm{~b})$ ), it appears that low $K_{s}$ values in low regions (Fig. [5.(b)) limit the amount of $E T_{\text {act }}$ (Fig. [7(b)). The effect of urban areas is also shown in both $E T_{a c t}$ and potential recharge as it was assumed that in these areas all rainfall is converted into runoff. The distribution of soils is also noticed in the spatial distribution of these two variables in the Sierra Nevada for 1982 as potential recharge values are clearly influenced by the large permeability values of Regosol.

Potential aquifer recharge is larger in the Sierra Chichinautzin the Sierra Nevada and the Sierra de Guadalupe for these four years (Fig,7(c)). In the Sierra Chichinautzin there is a clear pattern in the Tláloc and Ajusco peaks, where even though $E T_{a c t}$ is large as they are covered by forests, Lithosols with a large $K_{s}$ and low Available Water Capacity (AWC, Table 2) are found. These large recharge rates can be assumed to go into recharging the aquifer, as they occur on top of the fractured quaternary basalt (areas without shadows in Fig. (7) with large $K_{v}$. As previously mentioned, the large $E T_{a c t}$ observed in the mountains is explained by the fact that $K_{c b}=0.8$ for forests, which was assumed to be constant through the entire year and the fact that the largest precipitation rates occur in this region (i.e. even if $K_{c b}$ is large, without water there would not be $\left.E T_{a c t}\right)$. In order to analyze how the different vegetation coefficients vary with time and within each vegetation type, four vegetation types located in different soil types were chosen for 1981: grassland on Andosol, forest in Regosol, shrub in Phaeozem and rain-fed agriculture in Phaeozem (Fig. 8). As can be observed in this figure, both the grassland and forest sampling points are located in regions with large precipitation (Sierra de las Cruces and Sierra Nevada, respectively), while the shrub and rain-fed agriculture sampling points are located in Hidalgo, which is the region that receives less precipitation (Fig. 7 ).

The interaction of the different vegetation coefficients: $K_{c b}$, Soil evaporation 
(a) grassland

(b) $\begin{aligned} & \text { forest } \\ & \text { regosol }\end{aligned}$
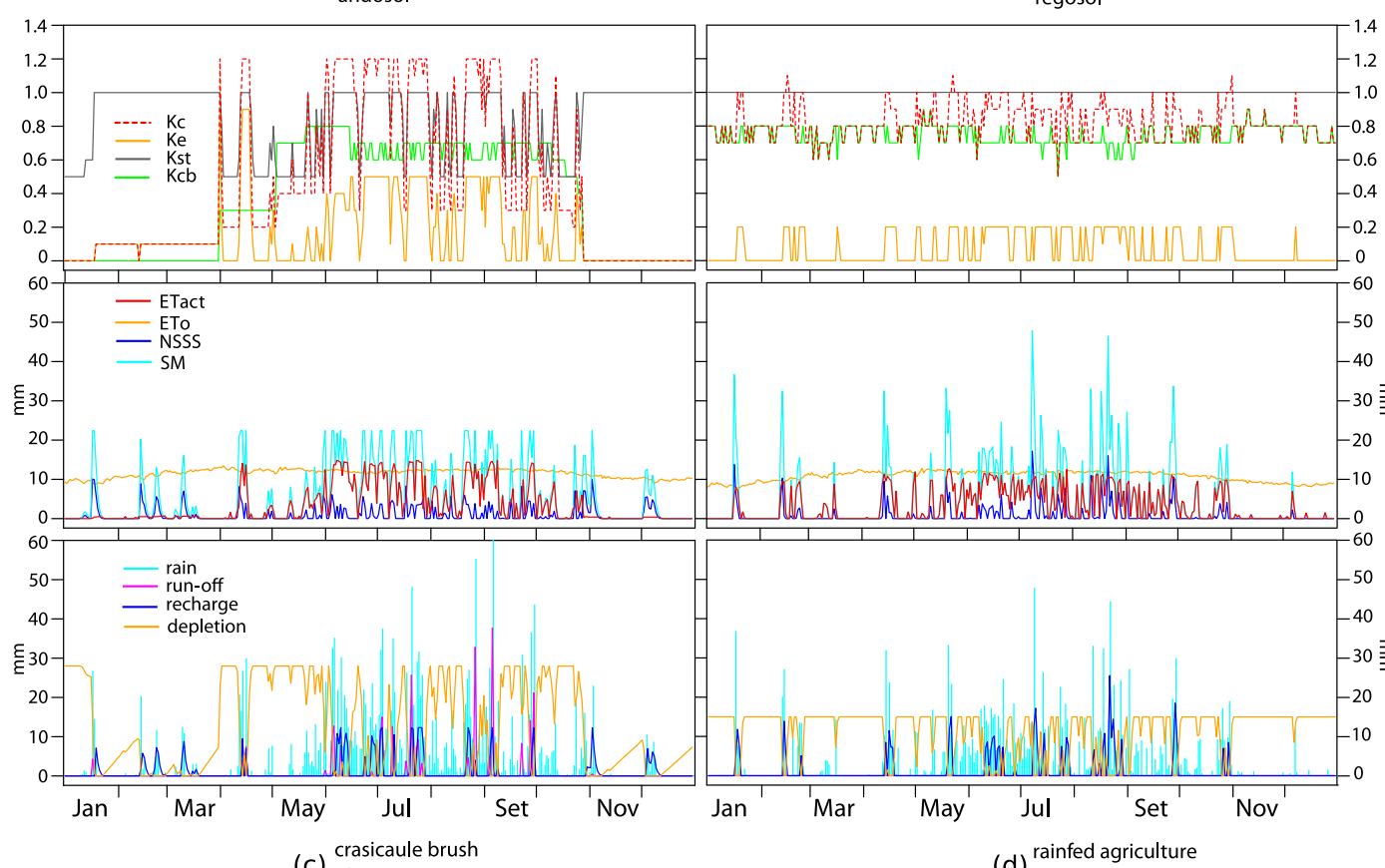

(c) $\begin{aligned} & \text { crasicaule b } \\ & \text { phaeozem }\end{aligned}$
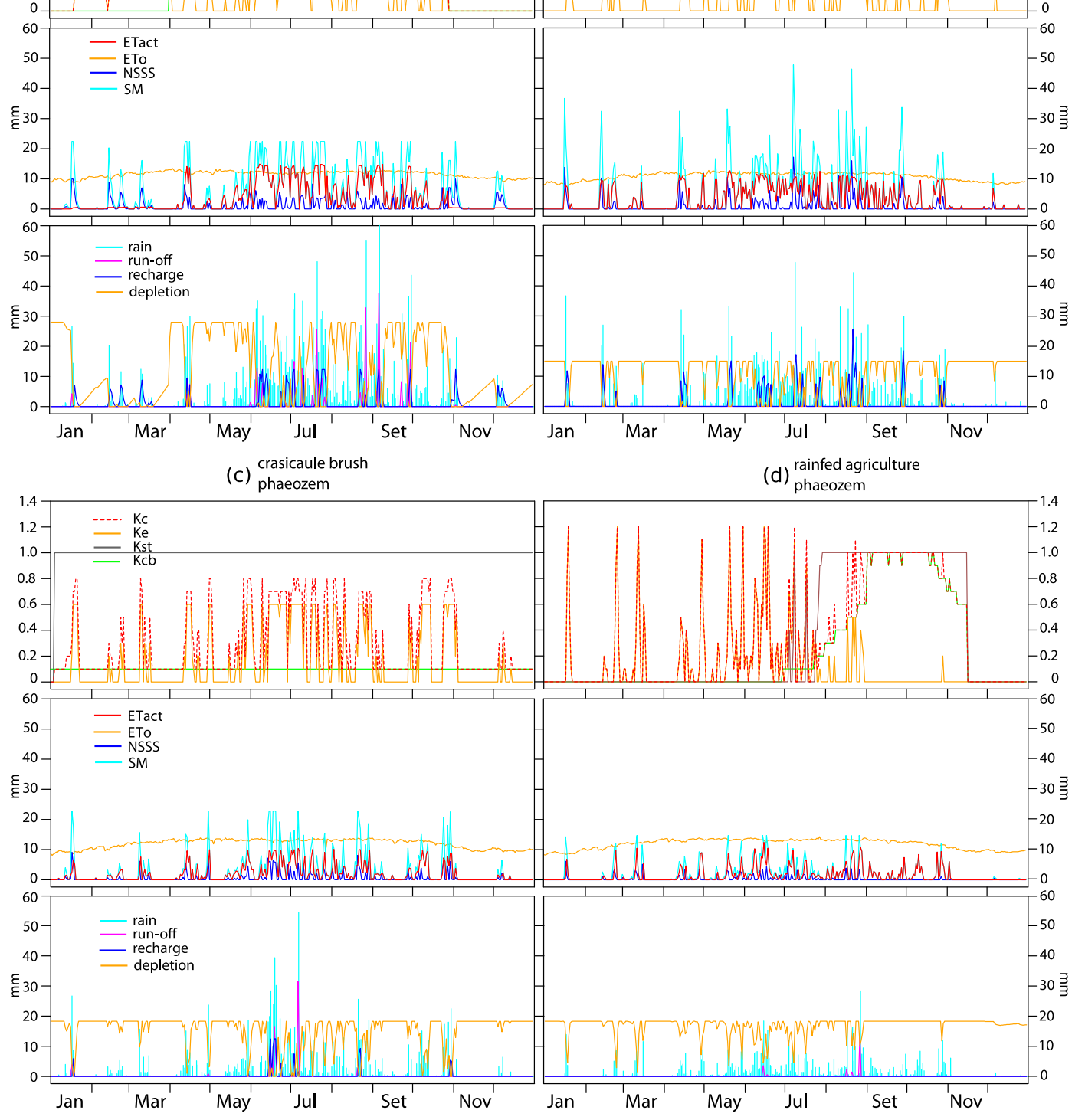

Fig. 8. Evolution of crop coefficients, evapotranspiration (both potential and actual), soil moisture, near surface soil storage (Nsss), rainfall, runoff, soil depletion and recharge in four different vegetation types: (a) grassland in andosol, (b) forest in regosol, (c) crasicaule bush in phaeozem and (d) rain-fed agriculture in phaeozem for 1981

$\left(K_{e}\right)$ and actual evapotranspiration $\left(K_{c}\right)$ is shown in the upper plots of Fig. $8(a-d)$, where it can clearly be seen that $K_{c}$ represents both $K_{c b}$ and $K_{e}$; these plots also show how $K_{c b}$ varies throughout the year according to each vegetation type: grassland was considered to be in a dormant state for the 
first three months of the year, as its $K_{c b}$ value increases in time, it is corrected when $\mathrm{RH} 45 \%$ through (7). It can also be noted that soil evaporation only occurs when there is soil moisture and that sometimes water that enters the soil is entirely used by the plants, as occurs for forested areas in March (Fig. 8(b)). For both grassland and forest areas (Fig.8(a),(b)) on some days $E T_{a c t}$ is equal to or larger than $E T_{\circ}$, caused by considering evaporation from the soil. As can be seen, the soil's depletion is bounded; this maximum value was set equal to the Total Evaporable Water (TEW) as suggested in Allen et al. (1998). This figure also shows how potential recharge only occurs when the soil's depletion is equal to zero, which occurs when the available soil moisture satisfies the ET needs and that this situation is required in order for Near Soil Surface Storage (NSSs) to occur as well. Soil evaporation is an important component for both shrub areas and rain-fed agriculture; even though shrub areas have a low $K_{c b}$ (Fig. 8 (c)) the soil component makes $K_{c}$ reach a value of 0.8 in several days, which in turn makes less water available for deep percolation; the same pattern is observed in the rain-fed plot (Fig. 8(d)): for the six months where no vegetation is present, $K_{c}$ reaches values of 1.2 .

Finally, Fig. 8 clearly shows the effect that both vegetation and soils have on potential aquifer recharge. This can be easily explained as the soil's physical properties have an effect both on rainfall partitioning and on Available Water Capacity (AWC). Soils with low $K_{s}$ and large AwC values (such as the lower areas in the Sierra de las Cruces, Fig. 5) will most certainly experience low recharge rates as the amount of water that can replenish the soil's water deficit is limited. Evidently the main driver of aquifer recharge is rainfall, but the soil/plant interaction plays an important role on the amount of water available for recharge. A rainfall event of $25 \mathrm{~mm}$ in forest areas (April , Fig. 8(b)) produced a $10 \mathrm{~mm}$ recharge value, while a $30 \mathrm{~mm}$ precipitation event caused no recharge in the sample point located in rain-fed agriculture (August, Fig. 8(d)), as almost all water was used by the plants and the remaining water was used to diminish the soil's water deficit. As June 1981 was the month with the largest rainfall, evapotranspiration and potential recharge, the monthly variability of this year is analyzed in the following section. 
The spatial distribution of rainfall, $E T_{a c t}$ and potential recharge of Fig. 7 show that for that particular month, 1981 was the year with the largest rate for the three variables. Accordingly, this year is used in this section to analyze how recharge varies through the year considering a monthly aggregation period (though the soil water balance was run at a daily time-step). The monthly recharge values for 1981 (Fig. 9) show that for this year, June was the month with the largest rate of potential aquifer recharge. The recharge pattern observed for the 12 months is similar, as the largest rates are found south of the Basin, in the Chichinautzin and Nevada Sierras; however the recharge pattern in the Sierra de las Cruces changes, as even though the soil units and vegetation cover are the same, larger recharge rates are observed in this Sierra's northern region. For this year, the three months with the largest rates of potential aquifer recharge are June, July and August with an equivalent flow of $87.9,41.1$ and $36.6 \mathrm{~m}^{3} / \mathrm{s}$ (or $23.7,11.1$ and $9.9 \mathrm{~mm}$ ) respectively (Fig. 9), while December and November have the lowest rates ( 1 and $4.5 \mathrm{~m}^{3} / \mathrm{s}$ ). The spatial pattern observed in Fig. 7 and Fig. 9 is also observed for all years from 1975 to 1986 (Fig. 10) as again, large recharge rates are observed in the same regions previously discussed.

On an annual basis (1975-1986), the year with the largest potential recharge rates is 1981, with an annual lumped flow rate value of $23.8 \mathrm{~m}^{3} / \mathrm{s}(78.1 \mathrm{~mm})$, while the lowest lumped flow rate of $10.9 \mathrm{~m}^{3} / \mathrm{s}(35.9 \mathrm{~mm})$ was obtained for 1977. As for the monthly recharge rates (Fig. 9), the same spatial pattern is observed as for the annually-aggregated recharge values (Fig. 10) with the exception of some spots located in the Basin's northern region for years 1975, 1980, 1981 and 1986. The large rates in those areas are explained by the fact that they are covered by shrub (Fig. 4), having a low $E T_{\text {act }}$ rate $\left(K_{c b}=0.15\right)$, which helps to improve recharge as a vegetation cover factor $\left(f_{c}\right.$, eq. (13) ) of 0.5 was also assumed, which in turn decreases the amount of water that evaporates from the soil. When this decrease is considered together with the plant's water requirements, which are low, more water is available for recharge.

The lumped annual recharge values obtained with this methodology for 1975-1986 (10.9-23.8 $\left.\mathrm{m}^{3} / \mathrm{s}\right)$, when compared to previous estimates in the 
${ }_{693}$ study area yield similar results: Birkle et al. (1998) estimated a recharge flow

694 range of $13-18.8 \mathrm{~m}^{3} / \mathrm{s}$ for the region where the MCMZ is located, while the 695 DGCOH (1994) estimated a recharge value of $15.6 \mathrm{~m}^{3} / \mathrm{s}$ in the same area; how696 ever, Durazo and Farvolden (1983) estimated a recharge flow of $55 \mathrm{~m}^{3} / \mathrm{s}$, 697 which seems to be too high when comparing it to the previously mentioned 698 studies. 


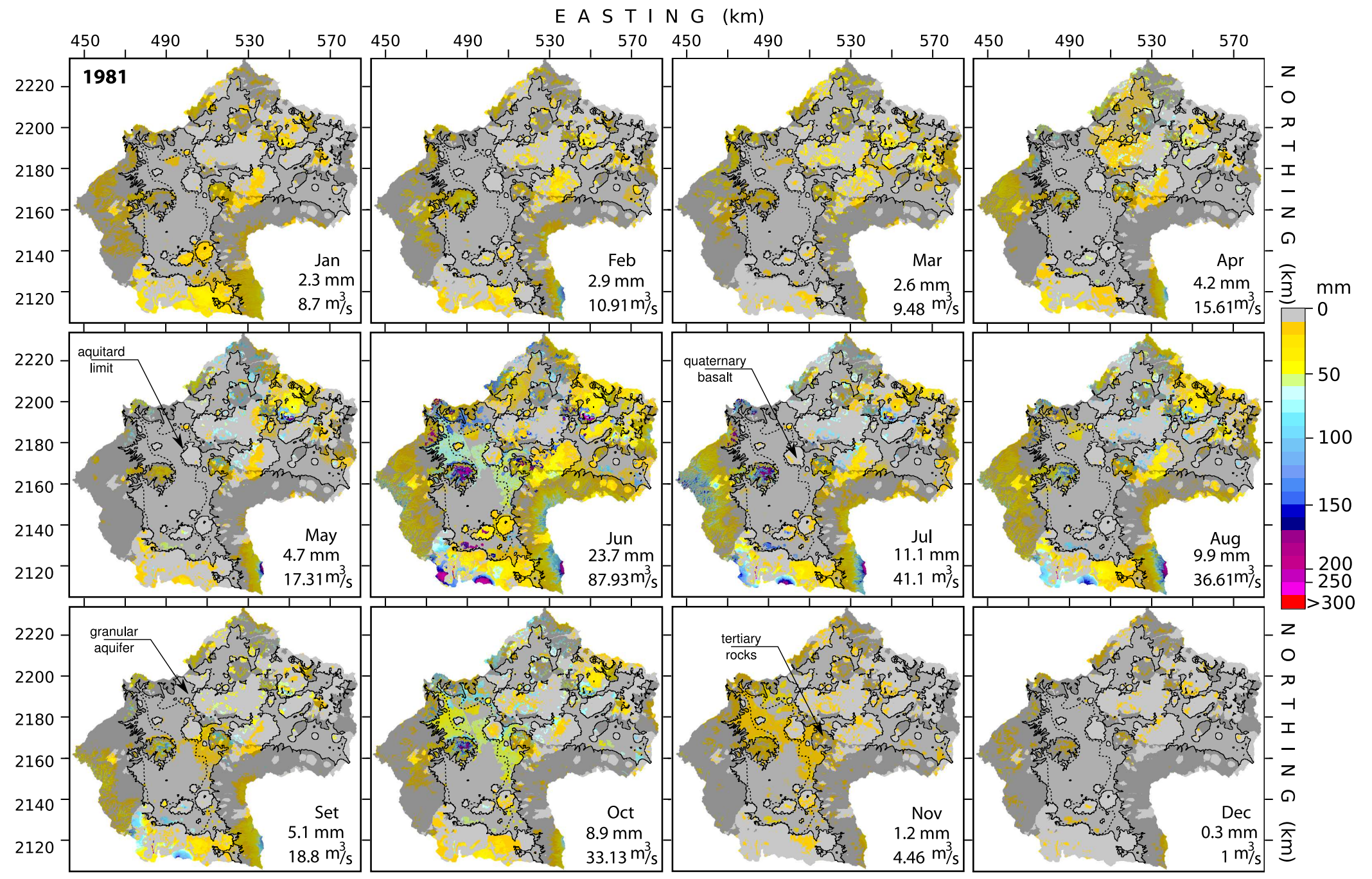

Fig. 9. Monthly spatial distribution of potential aquifer recharge in the Basin of Mexico for 1981. Dark-shadowed areas represent tertiary rocks, while light-shadowed areas represent the granular aquifer. Quaternary basalts are not covered by shadows. 


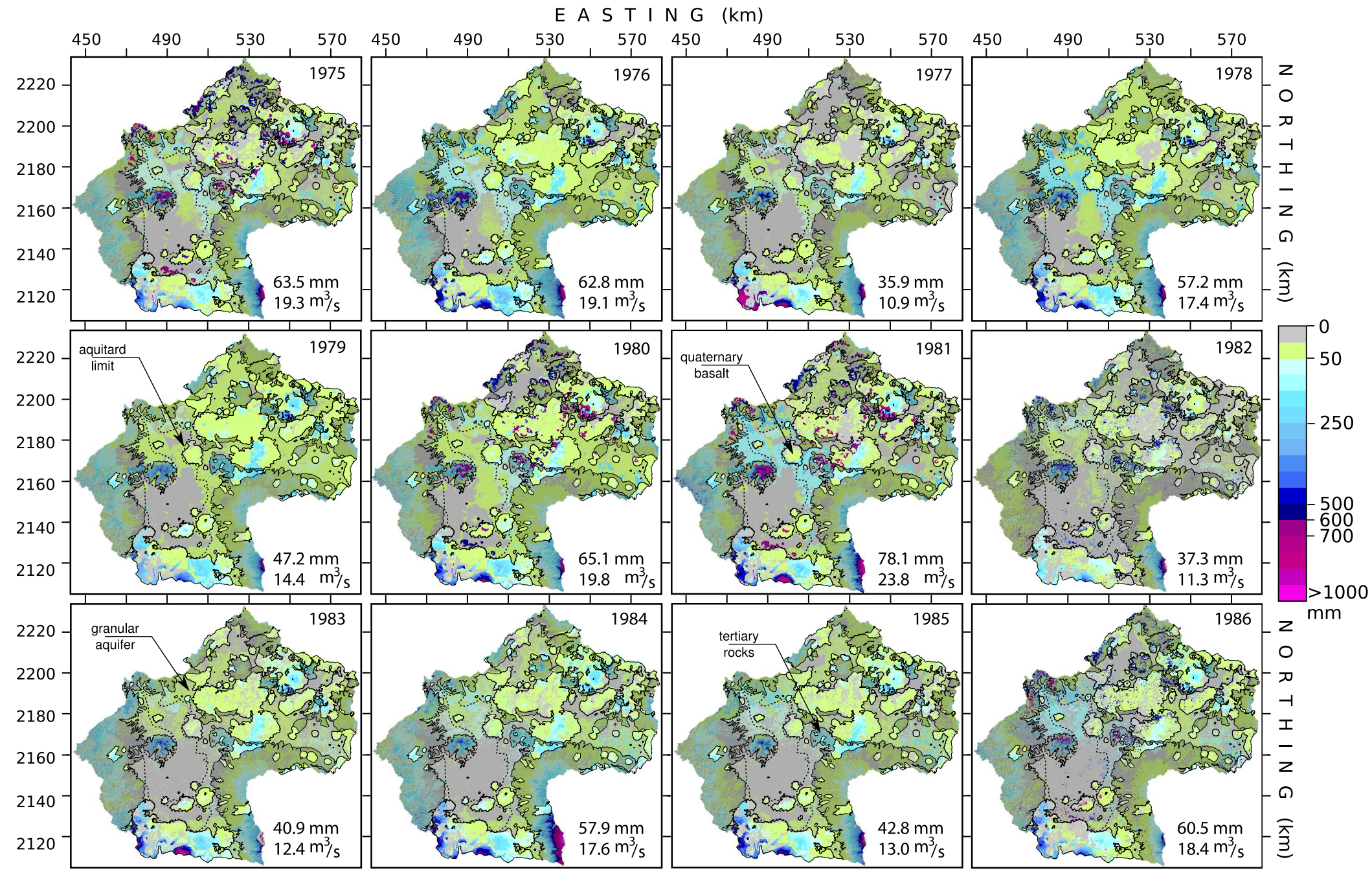

Fig. 10. Spatial distribution of accumulated annual recharge for 1975-1986. Dark-shadowed areas represent tertiary rocks, while light-shadowed areas represent the granular aquifer. Quaternary basalts are not covered by shadows. 
In order to analyze the impact of land cover change on potential aquifer recharge, 1981 was chosen, as this year has the largest recharge rates for the analyzed years (Fig. 10). The analysis, which consisted of running the daily soil water balance using the climatological variables of 1981 and the urban distribution for 1985 was limited to the Basin's western region, as this is where the MCMz is located; in addition, the analysis excluded the area covered by the aquitard (shown as a dashed line in Figs. 7.9 and 10) as this geological unit can be considered to be impermeable. This part of the alluvial plain, received an equivalent recharge flow of $1.9 \mathrm{~m}^{3} / \mathrm{s}$ (the entire Basin received a rate of $23.77 \mathrm{~m}^{3} / \mathrm{s}$ as shown in Fig. 10) while when the 1985 urban area was used, this flow diminished to $1.6 \mathrm{~m}^{3} / \mathrm{s}$, which implies a reduction of nearly $20 \%$ caused by urban growth in this region. However, when the entire Basin is considered, recharge is only diminished by $1.5 \%$. As can be seen in Figs. 7,9 and 10 the maximum recharge rates occur in areas which due to their topography have been "preserved" from urban growth (Fig. 圆).

\section{Conclusions}

This work has shown the development of a daily soil water balance which can be applied using data generally available in large scale studies. Through the application of this model, it has been shown that the mountains that enclose the Basin of Mexico are the main recharge areas of the Basin's regional aquifer system. The spatial distribution of potential aquifer recharge in the Basin is not uniform, as the largest rates are found south of the Basin, where rainfall is influenced by topography and where soils have large permeability values.

From the analyses developed in this work it can be concluded that although the main driver of aquifer recharge is rainfall, by itself it can not be used to estimate the spatial distribution of potential aquifer recharge as vegetation and soils also play an important role. The soil's physical properties affect the way in which rainfall is partitioned into runoff and water that enters the soil water balance, as well as the soil's Available Water Capacity (AWC): soils 

with low conductivity values and large AWC will experience low recharge rates as the amount of water that can replenish the soil's water deficit is limited. Vegetation also needs to be considered as for a given soil and rainfall depth a plant with low water requirements will take less water from the soil thus leaving more water available for recharge once the soil reaches field capacity.

The spatially distributed values of potential aquifer recharge, on an annual basis for the $1975-1986$ period, range from $10.9 \mathrm{~m}^{3} / \mathrm{s}$ for 1977 to $23.8 \mathrm{~m}^{3} / \mathrm{s}$ for 1981 while the monthly values for 1981 range from $1 \mathrm{~m}^{3} / \mathrm{s}$ in December to $87.9 \mathrm{~m}^{3} / \mathrm{s}$ in June. As aquifer recharge in the Basin occurs in the form of MBR, urban growth has not had a serious impact on aquifer recharge: when considering potential recharge in the alluvial plain, where the MCMZ is located, the equivalent recharge flow in 1981 was $1.9 \mathrm{~m}^{3} / \mathrm{s}$, which was diminished by nearly $20 \%$ (to $1.56 \mathrm{~m}^{3} / \mathrm{s}$ ) when the 1985 urban area was used for the same year. The explanation for this small change is that the MCMZ extends over an area which is mainly covered by lacustrine deposits, where recharge is negligible. In this regard it can be said that the Basin's geological environment has protected the aquifer: the lacustrine deposits with their low conductivity values have protected the aquifer from pollution, while the mountainous terrain, where recharge occurs, is protected from urban growth due to its topographic relief.

\section{A Equations to determine $E T_{\circ}$}

$$
\begin{aligned}
& \gamma=\frac{C_{p} P}{\varepsilon}=0.665 \times 10^{-3} P=0.665 \times 10^{-3} \times 101.3{\frac{293-0.0065 z^{5.26}}{293}}^{753} \\
& e_{s}=\frac{e^{\circ}\left(T_{\text {max }}\right)+e^{\circ}\left(T_{\text {min }}\right)}{2} \\
& { }^{754}(T)=0.618 \exp \frac{17.27 T}{T+237.7} \\
& { }_{755}^{\circ} \\
& \Delta=\frac{0.618 \exp \frac{17.27 T}{T+237.3}}{(T+237.3)^{2}}
\end{aligned}
$$


where $T$ represents daily average temperature:

$$
T_{\text {mean }}=\frac{T_{\text {max }}+T_{\text {min }}}{2}
$$

\section{References}

Allen, R., Pereira, L. S., Raes, D., and Smith, M. (1998). Crop evapotranspiration: Guidelines for computing crop water requirements. Irrigation and Drainage Paper No. 56. FAO, Rome, Italy.

Allen, R. G. (2000). Using the FAO-56 dual crop coefficient method over an irrigated region as part of an evapotranspiration intercomparison study. J. of Hydrology, 229:27-41.

Allen, R. G., Pruitt, W. O., Raes, D., Smith, M., and Pereira, L. S. (2005). Estimating evaporation from bare soil and the crop coefficient for the initial period using common soils information. J. of Irrigation and drainage engineering, 131(1):14-23. DOI:10.1061/(ASCE) 0733-9437(2005) 131:1(14).

Batjes, N. H. (1996). Development of a world data set of soil water retention properties using pedotransfer rules. GEODERMA, 71:31-52.

Bell, M. A. (1993). Organic matter, soil propertires and wheat production in the high Valley of Mexico. Soil Science, 156(2):86-93.

Berndtsson, R. and Larson, M. (1987). Spatial variability of infiltration in a semi-arid environment. J. of Hydrology, 90:117-133.

Beven, K., Lamb, R., Quinn, P., Romanowicz, R., and Freer, J. (1990). TOPMODEL, chapter 18, pages 627-668. Computer models of watershed hydrology. Water Resources Publications, CO., U.S.A.

Birkle, P., Torres-Rodriguez, V., and González-Partida, E. (1998). The water balance for the Basin of the Valley of Mexico and implications for future water consumption. Hydrogeology Journal, 6:500-517.

Bouman, C. A. and Shapiro, M. (1994). A multiscale random field model for bayesian image segmentation. IEEE Trans. on Image Processing, 3(2):162177.

Carlson, T. N. and Ripley, D. A. (1997). On the relation between NDVI, fractional vegetation cover and leaf area index. Remote Sensing of Environment, 62:241-252.

Carrera-Hernández, J. J. (2007). Spatio-temporal analysis of aquifer recharge and groundwater potentiometric levels in the Basin of Mexico through the development of a regional database and an open source tool for groundwater flow 
modelling. PhD thesis, McGill University. Available for download at http://escholarship.mcgill.ca/.

Carrera-Hernández, J. J. and Gaskin, S. J. (2007a). The Basin of Mexico aquifer system: regional groundwater level dynamics and database development. Hydrogeology journal. In press.

Carrera-Hernández, J. J. and Gaskin, S. J. (2007b). The Basin of Mexico Hydrogeological Database (вмнDв): Implementation, basic queries and interaction with open source software. Environmental Modelling $\mathcal{E}$ Software. In review.

Carrera-Hernández, J. J. and Gaskin, S. J. (2007c). Spatio temporal analysis of daily precipitation and temperature in the Basin of Mexico. Journal of Hydrology, 336,(3-4):231-249. DOI: 10.1016/j . jhydrol.2006.12.021.

Chavez, P. S. (1988). An improved dark object subtraction technique for atmospheric scattering correction of multispectral data. remote sensing of Environment, 24:459-479.

Chavez, P. S. (1996). Image-based atmospheric corrections - Revisited and Improved. Phot. Eng. E Rem. Sens., 62(9):1025-1036.

de Vries, J. J. and Simmers, I. (2002). Groundwater recharge: an overview of processes and challenges. Hydrogeology journal, 10:5-17.

DGCOH (1994). Diágnostico del estado presente de las aguas subterráneas de la ciudad de méxico y determinación de sus condiciones futuras (diagnosis of the present state of groundwater in mexico city and its future condition). Technical report, Instituto de Geofísica, UNAM.

Durazo, J. and Farvolden, R. (1983). The groundwater regime of the valley of mexico from historic evidence and field observations. J. of Hydrology, 112:171-190.

FAO (2001). Lecture notes on the major soils of the world. Technical report, Food and Agriculture Organization of the United Nations.

Fayer, M. J., Gee, G. W., Rockhold, M. L., Freshley, M. D., and Walters, T. B. (1996). Estimating recharge rates for a groundwater model using a GIS. J. Environ. Qual., 25:510-518.

Finch, J. W. (1998). Estimating direct groundwater recharge using a simple water balance model - sensitivity to land surface parameters. J. of Hydrology, 211:112-125.

Flint, A. L., Flint, L. E., Kwicklis, E. M., Fabryka-Martin, J. T., and Bodvarsson, G. S. (2002). Estimating recharge at yucca mountain, nevada, USA: compariosn of methods. Hydrogeology Journal, 10:180-204. 
Harbaugh, A. W. (2005). The U.S. Geological Survey Modular Ground-Water model: The ground water flow process, chapter 16 of Book 6: Modeling Techniques, Section A. Ground Water. U.S. Geological Survey.

Herrera, I., Martí nez, R., and Hernández, G. (1989). Contribución para la administración científica del agua subterránea de la Cuenca de México. Geof. Internacional, 28-2:297-334.

Huizar-Álvarez, R., Hernández, G., Carrillo-Martinez, M., Carrillo-Rivera, J. J., Hergt, T., and Angeles, G. (2003). Geologic structure and groundwater flow in the Pachuca-Zumpango sub-basin, central Mexico. Environmental Geology, 43(4):385-399.

Hutchinson, M. F. and Galland, J. C. (1999). Representation of terrain. In Longley, P. A., Goodchild, M. F., Maguire, D. J., and Rhind, D. W., editors, Geographical Information Systems, pages 105-124. John Wiley and Sons.

Islebe, G. A. and Velázquez, A. (1994). Affinity among mountain ranges in Megamexico: A phytogeographical scenario. Vegetatio, 115:1-9.

Itten, K. I. and Myer, P. (1993). Geometric and radiometric correction of TM data of mountainous forested areas. IEEE transactions on geoscience and remote sensing, 31(4):764-770.

Keese, K. E., Scanlon, B. R., and Reedey, R. C. (2005). Assessing controls on diffuse groundwater recharge using unsaturated flow modeling. Water Resources Research, 41(Wo6010):1-12.

Kirkby, M. J. (1975). Hydrograph Modelling Strategies, pages 69-90. Process in Physical and Human Geography. Heinemann.

Lerner, D. N., Isaar, A. S., and Simmers, I. (1990). Groundwater recharge: A guide to understanding and estimating natural recharge., volume 8 of IAH International contributions to hydrogeology. Verlag Heinz Heise.

Liang, S. (2001). Narrowband to broadband conversions of land surface albedo. Remote Sensing of Environment, 76:213-238.

Maurer, D. K., Berger, D. L., and Prudic, D. E. (1996). Subsurface flow to eagle valley from vicee, ash, and kings canyons, carson city, nevada, estimated from darcy's law and the chloride-balance method. Technical Report WRI 96-4088, USGS, Denver, CO.

McCauley, J. D. and Engel, B. A. (1995). Comparisons of scene segementations: SMAP, ECHO and Maximum Likelihood. IEEE transactions on Geoscience and Remote Sensing, 33:1313-1316.

Merz, B. and Plate, E. J. (1997). An analysis of the eeffects of spatial variability of soil and soil moisture on runoff. Wat. Res. Research, 33(12):2909-2922. 
Mitasova, H. and Mitas, L. (1993). Interpolation by regularized spline with tension: I. theory and implementation. Math. Geol., 25:641-655.

Mooser, F. and Molina, C. (1993). Nuevo modelo hidrogeológico para la Cuenca de Mexico. Boletin del centro de investigacion sismica Fundacion Barros Sierra.

Mu, Q., Heinsch, F. A., Zhao, M., and Running, S. W. (2007). Development of a global evapotranspiration algorithm based on MODIs and global meteorology data. Remote Sensing of Environment, 111:519-536.

Niswonger, R. G., Prudic, D. E., and Regan, R. S. (2006). Documentation of the Unstaurated-Zone Flow (UZF1) package for modeling unsaturated flow between the land surface and the water table with MODFLOW-2005, chapter 19 of section A, Ground Water of Book 6, Modeling Techniques. United States Geological Survey.

Ortega, A. and Farvolden, R. N. (1989). Computer analysis of regional groundwater flow and boundary conditions in the basin of mexico. J. of Hydrology, 110:271-294.

R Development Core Team (2005). R: A language and environment for statistical computing. R Foundation for Statistical Computing, Vienna, Austria. ISBN 3-900051-07-0.

Rawls, W. J. and Pachepsky, Y. A. (2002). Using field topographic descriptors to estimate soil water retention. Soil Science, 167(7):423-435.

Rushton, K. R., Eilers, V. H. M., and Carter, R. C. (2006). Improved soil moisture balance methodology for recharge estimation. Journal of Hydrology, 318:379-399.

Rzedowski, J. (1975). An ecological and phytogeographical analysis of the grasslands of Mexico. Taxon, 24(1):67-80.

Sánchez-González, A. and López-Mata, L. (2005). Plant species richness and diversity along an altitudinal gradient in the Sierra Nevada, Mexico. Diversity and Distributions, 11:567-575.

GRASS development team (2007). GRASS GIS software. sc itc-irst, Trento, Italy. Scanlon, B. R., Healy, R. W., and Cook, P. G. (2002). Choosing appropriate techniques for quantifying groundwater recharge. Hydrogeology journal, 10:18-39.

Sjoberg, R. W. and Horn, K. P. (1983). Atmospheric effects in satellite imaging of mountainous terrain. Applid Optics, 22(11):1702-1716.

Sophocleous, M. (1995). Groundwater recharge estimation and regionalization: the Great Bend Prairie of central Kansas and its recharge statistics. 
J. of Hydrology, 137:113-140.

Strozzi, T., Wegmüller, U., Werner, C. L., Wiesman, A., and Spreckels, V. (2003). JERS SAR interferometry for land subsidence monitoring. IEEE transactions on geoscience and remote sensing, 41:1702-1708.

Súri, M. and Hofierka, J. (2004). A new GIS-based solar radiation model and its application to photovoltaic assessments. Transactions in GIS, 8(2):175190.

Teillet, P. M., Guindon, B., and Goodenough, D. G. (1982). On the slopeaspect correction of multispectral scanner data. Canadian Journal of Remote Sensing, 8:84-106.

Vázquez-Sánchez, E. and Jaimes-Palomera, R. (1989). Geología de la cuenca de México. Geofísica Internacional, 28(2):133-190.

Wasiolek, M. (1995). Subsurface recharge to the tesuque aquifer systm from selected drainage basins along teh western side of the sangre de cristo moutnains near santa fe, new mexico. Technical Report WRI 94-4072, USGS, Denver, CO.

Wilson, J. L. and Guan, H. (2004). Mountain-block hydrology and mountainfront recharge. AGU, Washington, DC. 